\title{
Genomic basis and phenotypic manifestation of (non-)parallel serpentine adaptation in Arabidopsis arenosa
}

\author{
Veronika Konečná ${ }^{1,2^{*}}$, Marek Šustr ${ }^{3}$, Doubravka Požárová ${ }^{1}$, Martin Čertner ${ }^{1,2}$, Anna \\ Krejčová $^{4}$, Edita Tylováa ${ }^{3}$ and Filip Koláŕr ${ }^{1,2 *}$ \\ ${ }^{1}$ Department of Botany, Faculty of Science, Charles University, Benátská 2, 12800 Prague, \\ Czech Republic \\ ${ }^{2}$ Czech Academy of Sciences, Institute of Botany, Zámek 1, 25243 Průhonice, Czech \\ Republic \\ ${ }^{3}$ Department of Experimental Plant Biology, Faculty of Science, Charles University, \\ Viničná 5, 12800 Prague, Czech Republic \\ ${ }^{4}$ Faculty of Chemical Technology, University of Pardubice, Studentská 573, 53210 \\ Pardubice, Czech Republic
}

* e-mail: Veronika Konečná (konecnv@natur.cuni.cz) or Filip Kolář (filip.kolar@natur.cuni.cz)

\begin{abstract}
Parallel evolution is common in nature and provides one of the most compelling examples of rapid environmental adaptation. In contrast to the recent burst of studies addressing genomic basis of parallel evolution, integrative studies linking genomic and phenotypic parallelism are scarce. Edaphic islands of toxic serpentine soils provide ideal systems for studying rapid parallel adaptation in plants. Serpentines are well-defined by a set of chemical selective factors and recent divergence between serpentine and geographically proximal non-serpentine populations allow mitigating confounding effects of drift. We leveraged threefold independent serpentine adaptation of Arabidopsis arenosa and used reciprocal transplant, ionomics, and available genome-wide polymorphisms to test if parallelism is manifested to a similar extent at both genomic and phenotypic levels. We found the varying magnitude of fitness differences, that was congruent with neutral genetic differentiation between populations, and limited costs of serpentine adaptation. Further, phenotypic parallelism in functional traits was pervasive. The genomic parallelism at the gene level was significant, although relatively minor. Therefore, the similarly modified phenotypes e.g. of ion uptake arose possibly by selection on different loci in similar functional pathways. In summary, we bring evidence for the important role of genetic redundancy in rapid adaptation involving traits with polygenic architecture.
\end{abstract}

\section{INTRODUCTION}

Adaptation is a key evolutionary mechanism for how organisms can cope with changing environments. Identifying adaptation, however, is challenging at both phenotypic and genetic levels as multiple confounding signals such as evolutionary constraints, demographic or stochastic genetic processes may produce patterns resembling adaptation. Multiple populations facing the same environmental challenge provide strong evidence for repeated adaptation within a species. If the same phenotypes independently emerge in similar habitats, it is more probable that these features evolved under natural selection than solely due to the stochastic forces (Lenormand et al., 2009). The same adaptive phenotypes can have a divergent genetic basis when e.g. different genes within a pathway are under selection in different independent populations (e.g. Fang et al., 2021) or a similar genetic basis when a source for adaptation is a 
shared pool of standing variation or pleiotropic constraint (Hämälä and Savolainen, 2019). Despite numerous examples of parallel adaptation, however, we have still a limited understanding of the genetic basis of parallel phenotypic changes and their interplay with the local environmental conditions.

The strength of correlation between environmental factors and particular phenotypic traits, which are under the selection in multiple adapted populations, provide the system for quantification of the extent of parallelism. However, independently evolved 'adaptive' phenotypes are rarely identical, representing rather a continuum of non-parallel evolution (Stuart et al., 2017; Bolnick et al., 2018), in response to the complex interplay of the genetic basis of a trait, population history, and of local environmental heterogeneity (Rosenblum et al., 2014; Fraïsse and Welch, 2019; James, Wilkinson, et al., 2021). Indeed, the varying extent of phenotypic and genomic parallelism has been recently identified in many iconic examples of parallel evolution animals such as - threespine sticklebacks (Stuart et al., 2017; Magalhaes et al., 2021), salmonid fishes (Jacobs et al., 2020), guppies (Whiting et al., 2021), cichlids (Weber et al., 2021), marine snails (Morales et al., 2019), and songbirds (Salmón et al., 2021), but rarely investigated in plants (but see Knotek et al., 2020; James et al., 2021). For instance, Bohutínská et al. (2021) showed a divergence-dependent level of genomic parallelism in Brassicaceae i.e. with the increasing divergence between lineages the degree of gene reuse was decreasing. This is in congruence with findings in Senecio lautus (James, Arenas-Castro, et al., 2021; James, Wilkinson, et al., 2021), in which similar phenotypes with large divergence times withinpopulation pairs have arisen via mutational changes in different genes, although many of these genes shared the same biological functions. However, even in the system of recent post-glacial origin such as alpine populations of Heliosperma pusillum (Trucchi et al., 2017), they also achieved similar phenotypes via selection of different genes in the same functional pathways. In such polygenic systems we expect genetic redundancy, i.e. mutations in different genes (possibly within the same pathway) can lead to similar phenotypes and thus to phenotypic parallelism (Hermisson and Pennings, 2017; Höllinger et al., 2019; Barghi et al., 2020). In systems with high heterogeneity among the compared 'parallel' habitat types such as alpine stands, which may strikingly differ by a range of local parameters such as substrate and exposition, the extent of genomic and phenotypic parallelism may be underestimated. We thus need empirical evidence from other systems encompassing recent polygenic adaptation to more narrowly defined environmental challenges to explore if genetic redundancy can lead to phenotypic parallelism.

Naturally toxic edaphic substrates, serpentines, represent one of the most challenging extreme environments for plants. Unlike alpine or coastal environments, selective conditions of serpentines can be easily manipulated in the experimental conditions as specific soil chemistry is the principal defining selective factor of serpentine habitats. Serpentines are defined by a highly skewed $\mathrm{Ca} / \mathrm{Mg}$ ratio, high concentration of $\mathrm{Mg}$, and elevated heavy metals such as Cr, Co, and Ni (Brady et al., 2005; O'Dell and Rajakaruna, 2011). Although occurring worldwide, serpentine outcrops are typically scattered as small edaphic 'islands', being surrounded by other less toxic substrates. This setup triggers parallel evolution via repeated colonization from the surrounding non-toxic substrates, which has been recently shown in the case of an autotetraploid Arabidopsis arenosa (Konečná et al., 2021). In its genetically highly diverse autotetraploid cytotype, low neutral genetic differentiation and recent split times between geographically proximal serpentine and non-serpentine populations indicate recent postglacial serpentine invasions that happened at least five times independently (Konečná et al., 2021). Arabidopsis arenosa thus represents an ideal plant model for studying the repeatability of adaptation towards a well-defined selective environment. Yet, while finding significant parallelism at the genomic level, the extent of phenotypic parallelism across relevant 
fitness and physiological traits and the question of whether both levels correlate remained unknown.

Here, we used reciprocal transplants and asked to what extent the phenotypic evolution is repeatable during rapid parallel edaphic adaptation across three serpentine - non-serpentine A. arenosa population pairs. We hypothesize that in this recently postglacially diversified system with pervasive sharing of adaptive polymorphism (Konečná et al., 2021), genetic and phenotypic parallelism will be largely congruent. We quantified (i) genomic parallelism at genes (shared selection candidate loci) and functional pathways (shared gene ontology categories) and (ii) parallel phenotypic changes by scoring a diverse set of traits: fitness proxies, morphological functional traits and ion uptake. We specifically asked: (i) Do serpentine populations exhibit fitness differences in a direction corresponding to local substrate adaptation? If so, does the direction and magnitude of fitness response differ among population pairs in congruence with the level of neutral genetic differentiation? (ii) Is there a cost of serpentine adaptation (trade-off) and how its extent varies over the three parallel population pairs? (iii) Does the extent of phenotypic parallelism correspond to gene-level parallelism, or does the genetic redundancy lead to limited gene parallelism?

Local adaptation has been manifested in a congruent direction across all three parallel serpentine populations as the advantage of serpentine populations in their native soils and with utmost limited trade-offs. However, the magnitude of the adaptive response differed, following the level of genetic differentiation within population pairs. Further, we found pervasive phenotypic parallelism in functional traits with only a minority of traits showing non-parallel variation. Contrary to our initial hypothesis, gene-level parallelism was rare, especially when compared to high similarity in functional pathways. Likely, similar phenotypes arise mainly via selection of different genes in similar genetic pathways showing the role of genetic redundancy and stochasticity in rapid adaptation with polygenic basis.

\section{MATERIALS AND METHODS}

\section{Study species and environment}

Arabidopsis arenosa is an obligate outcrosser that is widespread on semi-open rocky habitats characterised by reduced competition on various substrates, predominantly on calcareous and siliceous non-serpentine soils across most of Europe (Schmickl et al., 2012). For this study we collected seeds from three autotetraploid serpentine (S1, S2, S3) and three geographically proximal (<19 km distant) sister non-serpentine siliceous populations in Central Europe (N1, N2, N3; STable 1; Konečná et al., 2021). The differences in elevation within the pairs were small for S1-N1 - $71 \mathrm{~m}$ and S2-N2 - $22 \mathrm{~m}$ and higher for S3-N3 - $322 \mathrm{~m}$, and the variation in local vegetation structure (open mixed/coniferous forests with rocky outcrops) and climatic variables among individual sites was negligible (Konečná et al., 2021). In contrast, we observed strong differences in soil chemistry, mainly driven by high level of heavy metals $(\mathrm{Co}, \mathrm{Cr}$, and $\mathrm{Ni}$ ), high concentration of $\mathrm{Mg}$, and low $\mathrm{Ca} / \mathrm{Mg}$ ratio consistently differentiating serpentine substrates occupied by the studied populations from their paired adjacent non-serpentine counterparts (see Konečná et al., 2021 for details) (also quantified in our set of populations, SFig. 1). Thus, we consider substrate adaptations as a primary source of selective divergence between replicated serpentine and non-serpentine populations and use different soils as experimental treatments in the analysis of serpentine adaptation.

\section{Reciprocal transplant experiment/ Plant cultivation}

To test for local substrate adaptation in the three serpentine - non-serpentine population pairs, we compared plant fitness in the native versus foreign soil in a reciprocal transplant experiment. 
We reciprocally transplanted plants of serpentine and non-serpentine origin from three population pairs $(\mathrm{S} 1-\mathrm{N} 1, \mathrm{~S} 2-\mathrm{N} 2, \mathrm{~S} 3-\mathrm{N} 3)$ that served as representatives of independent serpentine colonisations (Konečná et al., 2021). For each population pair, we transplanted young seedlings into serpentine and non-serpentine soils from their original sites (i.e., S1 plant cultivated in S1 and N1 soil and vice versa) in a common garden (Faculty of Science Charles University, $200 \mathrm{~m}$; methodological details are provided in Supplementary Methods) and tested for the interaction between the soil treatment and substrate of origin in selected fitness indicators (described further) as a proxy of local substrate adaptation. We observed initial differences already in germination and young rosette sizes (Konečná et al., 2021), and thus continued with the cultivation for the entire growing season until seed set.

\section{Trait scoring}

As the extent of the phenotypic parallelism is also dependent on the choice of measured traits, we scored a broad range of potentially relevant traits. Morphological traits directly linked to fitness (reproductive outputs) are the most obvious aims, in contrast, physiological or early developmental traits are only rarely scored due to technical limitations. To comprehensively explore the broad range of phenotypic variation we scored a diversity of functional traits. Specifically, we scored bolting and flowering time, rosette area, number of additive rosettes as morphological life-history traits and fruit production, total seed mass production, above ground and root biomass and survival as fitness proxies, ion uptake of five important elements characterizing serpentine substrate $(\mathrm{Co}, \mathrm{Cr}, \mathrm{Ni}, \mathrm{Ca}, \mathrm{Mg})$, and functional traits of root growth and architecture in seedlings - total root growth, main root length, and density of lateral roots in order to cover both early and later stages of plant development and both macroscopic and physiological properties. We included transitions to bolting, flowering, fruit production, and survival to cover all life stages.

We cultivated plants for 10 months (January - October 2019). We scored bolting time when the first flowering buds appeared on elongated stems (cca at least $1 \mathrm{~cm}$ tall) and flowering time as opening of the first flowers every three/four days. Further, we have measured the rosette area (which correlated with rosette diameter, see Konečná et al., 2021) in time of the maximum rosette diameter (SFig 6 in Konečná et al., 2021) in four months since germination. We have been collecting fruits regularly once/twice a week since mid-June (five months since germination), additionally, we collected fruits in two time points, when most plants produced matured fruits. We excluded fruits with less than five seeds, as those were possibly not well developed (mean number of seeds/fruit: 73). We provide the summary of flowering/fruit proportion of plants in STable 2. At the end of the experiment, we counted and weighted seeds per each harvested fruit (1-22 fruits/plant). We used this value of seed mass/fruit to calculate average seed mass/population/treatment, the total seed mass production was then calculated by multiplying the total number of fruits by average seed mass/population/treatment. To account for possible seasonal variability, we tested if seeds produced until the end of July varied in weight from those produced later in the summer and the autumn, but we did not find a significant difference. Next, we counted the total number of additive rosettes (plants produced additive sister rosettes) in early September, and we weighted the above-ground biomass (from all plants which survived) and root biomass (we randomly chose five plants/population/treatment due to challenging and time-consuming sample preparation) after the harvest at the end of October. Finally, we scored the survival of plants continuously and at the end of the experiment.

We quantified the concentration of the key serpentine-distinctive elements $(\mathrm{Ca}, \mathrm{Co}, \mathrm{Cr}$, $\mathrm{Mg}$, and $\mathrm{Ni}$ ) in randomly selected 10 individuals from each serpentine and non-serpentine population cultivated in serpentine treatments ( $\mathrm{S} 1, \mathrm{~S} 2$, and $\mathrm{S} 3$ ). We collected leaves in mid- 
May (after 2.5 months of cultivation in serpentine soils) and dried and decomposed samples prior to the analysis (see Supplementary Methods for details). To identify potential contamination of leaf samples we calculated the interquartile range (difference between the 75th percentile and the 25th percentile) for all values of heavy metals $(\mathrm{Co}, \mathrm{Cr}$, and $\mathrm{Ni}$ ) and removed all values (four samples, $6 \%$ of all samples, in total) which had 1.5 times the interquartile range greater than the third quartile.

\section{Root growth experiments in calcium/magnesium solutions}

To analyse response to altered $\mathrm{Ca} / \mathrm{Mg}$ ratio in the environments we conducted root growth experiments. We cultivated plants in vitro on agar-solidified media supplemented with various $\mathrm{Ca} / \mathrm{Mg}$ ratios -1.97 in control medium, 0.2 in medium simulating the mean $\mathrm{Ca} / \mathrm{Mg}$ ratio in natural serpentine populations involved in this study, and 0.04 in medium according to Bradshaw (2005). We measured the root traits (total root growth, main root length, and density of lateral roots) in plants 15 days since germination. Similarly to Berglund et al. (2004) we focused on root phenotypes, which directly mirror the stressful solutions, and they are visible even in the early stages of plant development. For cultivation details see Supplementary Methods.

\section{Statistical analysis of trait variation}

We assessed the variation in morphological life-history traits and fitness proxies by linear and generalized linear models (LM and GLM) and functional traits of root growth and architecture by linear mixed effect models (LMM). For each trait, we tested the effect of substrate of origin ( $\mathrm{S}$ vs. $\mathrm{N})$, population pair $(1,2,3)$, treatment ( $\mathrm{S}$ vs. $\mathrm{N}$ ) and their interactions. Traits with deviation from Gaussian distribution were log or square root transformed to approach normality (indicated in Table 1, STable 6, STable 7). We used random effects of cultivation run and Petri dish for cultivation in LMM. No pair of measured traits was highly correlated $(\mathrm{R}>0.8$, SFig. 2). Tests of significance for individual fixed-effect factors, substrate of origin, treatment, population pair, as well as the substrate of origin*treatment interaction were conducted by Type III Wald $\chi 2$ tests with the $\mathrm{R}$ package car.

We used aster models (Geyer et al., 2007; Shaw et al., 2008) to analyze the hierarchical composite fitness differences among populations separately within each soil treatment. This approach is suitable for combining multiple fitness traits with different distributions into a single composite fitness variable. The hierarchical structure of the model, however, did not allow to incorporate final harvested above-ground biomass (plants, which survived, but did not reproduce). For each individual, we used the following hierarchy: 1 -> bolting (Bernoulli distribution, 0/1) -> flowering (Bernoulli distribution, 0/1) -> fruit production (Bernoulli distribution, 0/1) -> total seed mass production (Poisson distribution). By comparing the nested models with the effect of substrate of origin, population pair, and their interaction using likelihood ratio tests, we found the model with the highest likelihood (substrate of origin* population pair) (STable 3). Using likelihood ratio tests, we also tested the differences between populations within population pairs in order to assess if populations significantly differ in composite hierarchical fitness.

The aster model does not allow to incorporate possibly an important indicator of success in next season - above-ground biomass of plants, which did not produce fruits. Therefore, to further quantify fitness response using all five scored fitness proxies, we multiplied flowering proportion and early survival, fruit production, total seed mass production, late survival after fruit production, and above-ground biomass for both serpentine and non-serpentine plants in their native and foreign soil. The values of total seed mass production and above-ground biomass were standardized by the average of the serpentine - non-serpentine plants control 
values from non-serpentine treatment for each pair separately to account for population-pair variation. Besides the phenological and reproductive traits, we also included late survival and above-ground biomass, proxies for the plant's success in the following year. Then, we used cumulative fitness to quantify the overall fitness trade-offs (cost of adaptation; following Hereford, 2009). We calculated the difference in relative fitness between a pair of serpentine and non-serpentine populations at each population's native soil. These estimates were standardized by relative mean fitness at each soil. Further, we evaluated the relative magnitudes of local adaptations to serpentine soils by comparing serpentine and non-serpentine plants within each population pair cultivated in serpentine soil (following Hereford, 2009). The magnitudes of adaptations were expressed in terms of specific differences between the substrate of origins. We calculated these values based on overall cumulative fitness estimates. The difference (native - foreign) represents the total increase in fitness due to local adaptation (if the values are positive).

We tested the differences in functional traits (morphological life-history traits and fitness proxies) and leaf elemental concentrations (ionomic phenotypes) between the group of serpentine and non-serpentine populations cultivated in the stress environment (serpentine soil) using LM with substrate of origin, population pair and their interaction as fixed effects. To assess the degree of parallelism and non-parallelism more quantitatively, effect sizes of each factor and their interaction were estimated from the output of LM models (trait $\sim$ substrate of origin + population pair + substrate of origin*population pair) using a partial eta-squared method (anova_stats function) in R sjstats package. Larger effect of the substrate of origin than the effect of the substrate of origin*pop. pair interaction was an indication of parallelism while the opposite implied non-parallel serpentine/non-serpentine differentiation in that particular trait (Stuart et al., 2017).

\section{Leaf and soil elemental concentration analyses}

We used the soil elemental composition data from natural populations from Konečná et al. (2021) to identify major drivers of substrate adaptation in three serpentine populations. We further quantified the elemental composition of soils used in the reciprocal experiment for direct associations with leaf elemental concentrations using inductively coupled plasma mass spectrometry (ICP-OES; spectrometer INTEGRA 6000, GBC, Dandenong Australia). We monitored five elements ( $\mathrm{Ca}, \mathrm{Co}, \mathrm{Cr}, \mathrm{Mg}$, and $\mathrm{Ni}$ ) in both soil and leaf extract samples. Soil samples, which were collected from five pots/population/treatment at the same time as leaf samples in mid-May, were mixed, sieved and dried at $60{ }^{\circ} \mathrm{C}$. Both soil and leaf samples were prepared according to a protocol summarised in Supplementary Methods.

\section{Quantification of gene parallelism}

We used already published individual resequencing data for serpentine (S1, S2, and S3) and non-serpentine (N1, N2, and N3) populations (7-8 individuals per population, 47 in total) from the study of Konečná et al. (2021). Raw data are available as a BioProject PRJNA667586 and PRJNA325082. To quantify the extent of gene parallelism we leveraged the threefoldreplicated natural setup and already identified candidate genes that show repeated footprints of selection across three events of serpentine colonization in Konečná et al. (2021). Briefly, differentiation candidates were identified as gene-coding loci exhibiting excessive differentiation between serpentine - non-serpentine populations within each population pair using $1 \%$ outlier FST window-based scans. Further, we identified parallel differentiation candidates as overlapping genes in differentiation candidate lists across at least two population pairs. We tested if such overlap is higher than a random number of overlapping items given the sample size using Fisher's exact test in SuperExactTest in R package (Wang et al., 2015). 
Further, we calculated the proportion of shared genes as number of shared differentiation candidate genes per each two population pairs divided by the total number of differentiation candidate genes for selected population pair combination.

\section{Gene Ontology (GO) enrichment analysis and quantification of functional parallelism}

To infer function-level parallelism, we annotated differentiation candidates into biological processes, molecular pathways, and cellular components using gene ontology (GO) enrichment analysis for each population pair separately. We applied Fisher's exact test with the classic algorithm implemented in the topGO R package (Alexa and Rahnenfuhrer, 2020). We worked with $A$. thaliana orthologs of $A$. lyrata genes obtained using biomaRt and $A$. thaliana was also used as the background gene universe in all gene set enrichment analyses. With the "classic" algorithm each GO term is tested independently and it is not taking the GO hierarchy into account. Therefore, it is more suitable for comparisons across multiple lists of candidates to get overall quantification of parallelism. We accepted only significant GO terms ( $p<0.05$, Fisher's exact test). We calculated the proportion of shared functions as the number of shared GO terms per each two population pairs divided by the total number of GO terms for selected population pair combination. In order to test if functional parallelism in GO terms is not driven solely by parallel differentiation candidate genes, we ran the same analyses also without these candidates.

\section{Functional protein association networks in STRING}

To search for functional associations among identified differentiation candidates from three population pairs, we used STRING v11 database (Szklarczyk et al., 2015) of protein-protein association networks. We used 'multiple proteins' search in Arabidopsis thaliana and these active interaction sources: co-expression, co-occurrence, databases, experiments, gene fusion, neighborhood, and textmining. We required the minimum interaction score of medium confidence (0.4) and retained only 1 st shell associations.

\section{RESULTS}

\section{Varying magnitude and direction of parallel serpentine adaptation in Arabidopsis arenosa}

In line with the hypothesis of parallel adaptation, originally serpentine populations grown in their native soils exhibited higher values in most of the fitness-related functional traits. Significant interaction of the substrate of origin with the soil treatment $(p<0.05$, Type III Wald $\chi 2$ tests, Table 1, SFig. 3) was observed for the rosette area, number of additive rosettes, total seed mass production, above-ground and root biomass, and total root growth. To further quantify overall fitness differences, we further combined the joint contribution of four reproductive fitness traits in hierarchical aster models, which explicitly test the dependence of particular reproductive fitness traits on the others together with the transition among them in each treatment (Fig. 1A). We observed significantly higher composite fitness for originally serpentine populations $\mathrm{S} 1$ and $\mathrm{S} 3$ grown in their native serpentine substrate as compared to their paired non-serpentine populations (Fig. 1A; 45.63 and 56.42, respectively; STable 4). The difference in population pair 2 was negligible, reflecting the overall very low survival of both populations $(62 \%)$ in serpentine soil 2 (STable 2). 
Table 1. Effects of substrate of origin ( $\mathrm{S}$ vs. N)/ population pair (1,2,3)/ treatment (S vs. N soil)/ and their interactions on functional traits were tested by linear models (LM), binomial generalized linear models (GLM binomial), and linear mixed effect models (LMM). Tests of significance for individual fixed effect factors and interaction were conducted by Type III Wald $\chi 2$ tests. The random effects in LMM were cultivation batch and Petri dish for cultivation. The last three traits were assessed in a separate experiment using growth media (treatment here is represented by different $\mathrm{Ca} / \mathrm{Mg}$ concentrations).

\begin{tabular}{|c|c|c|c|c|c|c|c|c|c|c|c|c|c|c|}
\hline \multirow[t]{2}{*}{ Response variable } & \multirow[t]{2}{*}{$\begin{array}{l}\text { Transfor- } \\
\text { mation }\end{array}$} & \multirow[t]{2}{*}{ Model } & \multicolumn{3}{|c|}{ Substrate of origin } & \multicolumn{3}{|c|}{ Pop. pair } & \multicolumn{3}{|c|}{ Treatment } & \multicolumn{3}{|c|}{$\begin{array}{l}\text { Substrate } \\
\text { origin*treatment }\end{array}$} \\
\hline & & & Df & $\chi^{2}$ & $p$ & Df & $\chi^{2}$ & $p$ & Df & $\chi^{2}$ & $p$ & Df & $\chi^{2}$ & $p$ \\
\hline Bolting time [days] & $\log$ & LM & 1 & 2.0524 & $\mathrm{n}$ & 2 & 26.3506 & $* * *$ & 1 & 6.8092 & $* *$ & 1 & 2.4737 & ns \\
\hline Flowering time [days] & $\log$ & LM & 1 & 0.0088 & ns & 2 & 3.5704 & $*$ & 1 & 5.5588 & $*$ & 1 & 0.0618 & ns \\
\hline Rosette area $\left[\mathrm{mm}^{2}\right]$ & sqrt & LM & 1 & 74.0269 & $* * *$ & 2 & 4.0045 & $*$ & 1 & 382.8176 & $* * *$ & 1 & 51.43337 & $* * *$ \\
\hline $\mathrm{N}$ of additive rosettes & $\log$ & LM & 1 & 34.4439 & $* * *$ & 2 & 9.9119 & $* * *$ & 1 & 91.4885 & $* * *$ & 1 & 14.2435 & $* * *$ \\
\hline $\begin{array}{l}\text { Probability of fruit } \\
\text { production }(0 / 1)\end{array}$ & & $\begin{array}{l}\text { GLM } \\
\text { binomial }\end{array}$ & 1 & 10.2295 & $* *$ & 2 & 3.576 & ns & 1 & 14.0429 & $* * *$ & 1 & 2.8821 & . \\
\hline $\begin{array}{l}\text { Total seed mass } \\
\text { production }[\mathrm{mg}]\end{array}$ & $\log$ & LM & 1 & 27.2423 & $* * *$ & 2 & 6.3113 & $* *$ & 1 & 26.9319 & $* * *$ & 1 & 12.6945 & $* * *$ \\
\hline $\begin{array}{l}\text { Above-ground } \\
\text { biomass [mg] }\end{array}$ & sqrt & LM & 1 & 9.6231 & $* *$ & 2 & 9.6957 & $* * *$ & 1 & 104.7775 & $* * *$ & 1 & 13.8185 & $* * *$ \\
\hline
\end{tabular}




\begin{tabular}{|c|c|c|c|c|c|c|c|c|c|c|c|c|c|c|}
\hline Root biomass [mg] & $\log$ & LM & 1 & 15.6522 & $* * *$ & 2 & 16.9575 & $* * *$ & 1 & 61.3215 & $* * *$ & 1 & 14.2662 & $* * *$ \\
\hline $\begin{array}{l}\text { Probability of late } \\
\text { survival (after fruit } \\
\text { production) }(0 / 1)\end{array}$ & & $\begin{array}{l}\text { GLM } \\
\text { binomial }\end{array}$ & 1 & 6.5438 & $*$ & 2 & 4.7977 & . & 1 & 8.0743 & $* *$ & 1 & 2.1933 & ns \\
\hline $\begin{array}{l}\text { Total root growth } \\
{[\mathrm{cm}]}\end{array}$ & $\log$ & LMM & 1 & 123.7103 & $* * *$ & 2 & 14.7846 & $* * *$ & 2 & 60.0113 & $* * *$ & 2 & 44.4136 & $* * *$ \\
\hline Main root length $[\mathrm{cm}]$ & & LMM & 1 & 16.4607 & $* * *$ & 2 & 8.9317 & $*$ & 2 & 24.9806 & $* * *$ & 2 & 6.2092 & $*$ \\
\hline $\begin{array}{l}\text { Density of lateral } \\
\text { roots (number of } \\
\text { lateral roots/main root } \\
\text { length) }\end{array}$ & sqrt & LMM & 1 & 12.9772 & $* * *$ & 2 & 17.5417 & $* * *$ & 2 & 20.2030 & $* * *$ & 2 & 8.0637 & $*$ \\
\hline
\end{tabular}



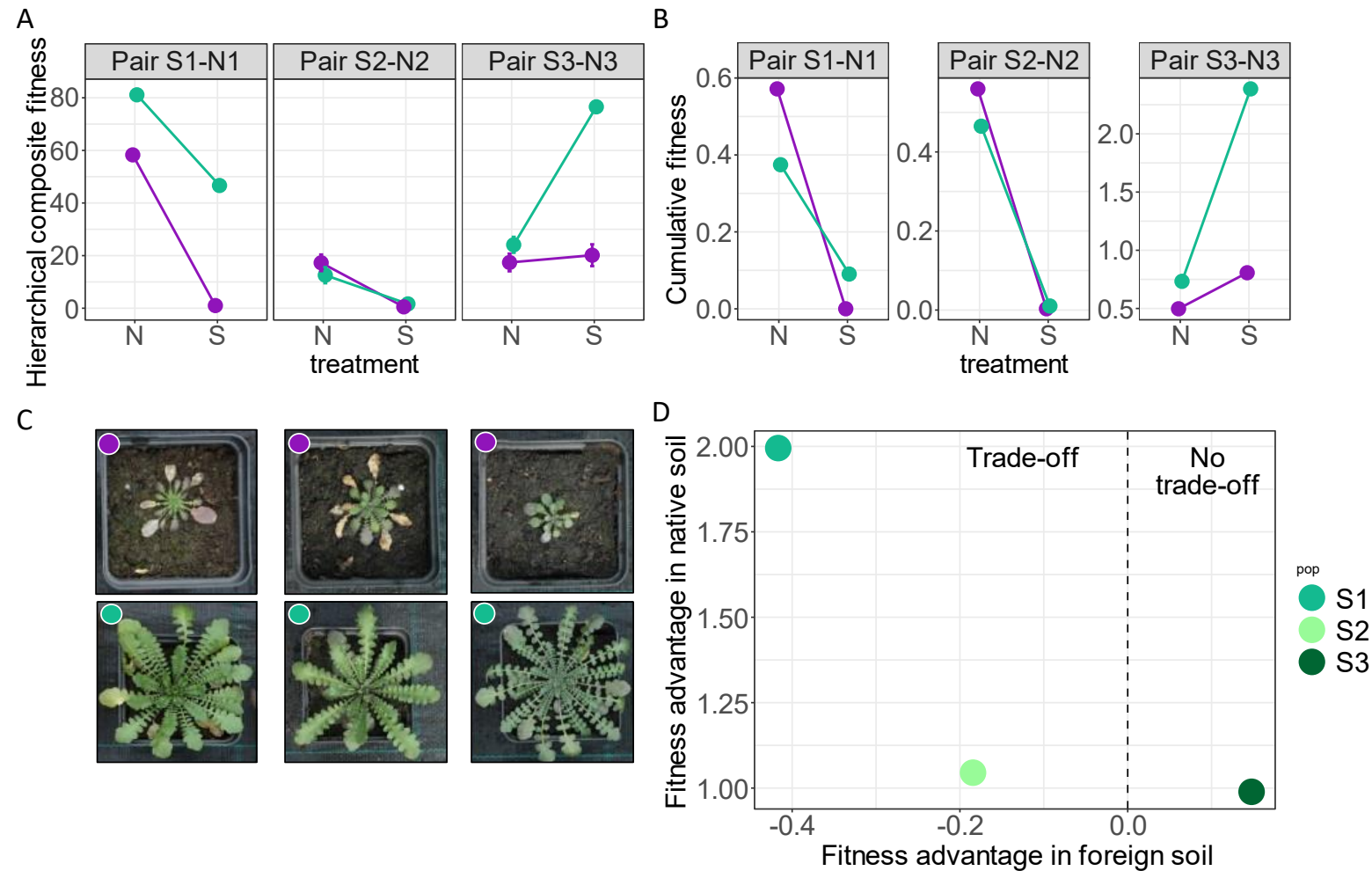

Fig. 1. Local adaptation to serpentine soils in three parallel population pairs of A. arenosa. A) Hierarchical composite fitness (+-SEs) for serpentine (green) and non-serpentine (violet) plants cultivated in local serpentine $(\mathrm{S})$ and non-serpentine $(\mathrm{N})$ soils. Estimates were taken from hierarchical aster models combining proportion of bolting plants, proportion of flowering plants, fruit production, and total seed mass. The significant $(p<0.001)$ interactions were found for the S1 - N1 and S3 - N3 population pairs (complete results in STable 4). B) Cumulative fitness calculated by combining five reproductive and vegetative traits (flower proportion and early survival, fruit production, total seed mass production, late survival after fruit production, and above-ground biomass). Note the $\mathrm{y}$-axes have been adjusted to different ranges to aid visibility. C) Example photos illustrating parallel response to serpentine soils (dot colours denote the plant origin; from the left: population pair $1-2-3$; photos taken by $\mathrm{V}$. Konečná). D) Relative fitness advantage of the originally serpentine population in its native and foreign (i.e. nonserpentine) soils calculated based on cumulative fitness estimates. On the left side, both populations from the pair (as we are addressing serpentine adaptation only serpentine populations are visualized) had higher relative fitness in their native soils indicating fitness trade-off. On the right side, the serpentine population had relatively higher fitness than non-serpentine population in both soil treatments. Note: each fitness advantage estimate was standardized by the relative mean fitness of plants at each soil treatment.

Further, we calculated cumulative fitness (STable 5) based on vegetative and reproductive fitness proxies, to quantify differences in the magnitude of local adaptation among population pairs (Fig. 1B). In all cases, the magnitude of local adaptation was positive (Table 2 ), which indicates the advantage of serpentine populations in their native soil and selection against immigrants (Hereford, 2009). Yet, the magnitude of this response differs among population pairs, which is in line with varying relative fitness differences already observed in aster models. We found the lowest value for population pair 2 and highest for pair 3 , which is fully in congruence with increasing genome-wide differentiation of population pairs $2<1<3$ (Table 2). Overall, serpentine populations have higher fitness in serpentine soils than their originally non-serpentine counterparts, although its magnitude strongly varied, altogether providing strong evidence for substrate-driven local adaptation. 
Table 2. Estimated magnitude of local adaptation in serpentine soils.

\begin{tabular}{|l|l|l|l|l|}
\hline $\begin{array}{l}\text { Population } \\
\text { pair }\end{array}$ & $\begin{array}{l}\text { Genetic } \\
\text { differentiation } \\
(\text { FsT })^{1}\end{array}$ & $\begin{array}{l}\text { Substrate } \\
\text { environmental } \\
\text { distance }^{2}\end{array}$ & $\begin{array}{l}\text { Magnitude of local } \\
\text { adaptation - }_{\text {cumulative fitness }}\end{array}$ & $\begin{array}{l}\text { Relative difference in } \\
\text { hierarchical } \\
\text { composite fitness }^{4}\end{array}$ \\
\hline S1-N1 & 0.069 & 4.174 & 0.090 & 45.635 \\
\hline S2-N2 & 0.029 & 6.682 & 0.007 & 1.129 \\
\hline S3-N3 & 0.085 & 6.934 & 1.579 & 56.414 \\
\hline
\end{tabular}

\footnotetext{
${ }^{1}$ inferred from genome-wide nearly-neutral fourfold degenerated single nucleotide polymorphisms (SNPs) by Konečná et al. (2021)

2 environmental distances were calculated based on chemical analysis of 20 elements in in soils sampled at original locations

${ }^{3}$ cumulative fitness gathered by multiplication of flower production and early survival, fruit production, total seed mass production, late survival after fruit production, and above-ground biomass

${ }^{4}$ inferred by hierarchical aster model performed on proportion of bolting plants -> proportion of flowering

plants -> fruit production -> total seed mass production
}

In line with the differences in the direction we also found variation in trade-offs. While population pairs 1 and 2 exhibited costs of serpentine adaptation in the non-serpentine soils (based on cumulative fitness values), a positive fitness advantage in the foreign non-serpentine soil was present in the S3 population (0.148), reflecting larger viability of S3 even in the nonserpentine soil (Fig. 1D). Yet, even in cases involving trade-offs, serpentine adaptation had a limited cost (1.52 average fitness advantage in native soil vs. -0.3 average fitness advantage in foreign soil, Fig. 1D). This is also in congruence with minor and nonsignificant differences in the survival of plants in non-serpentine treatment ( $89 \%$ survival of originally serpentine plants vs. $87 \%$ survival of originally non-serpentine plants).

\section{Varying levels of phenotypic parallelism across functional traits}

We further analyzed the magnitude of response to serpentine across distinct population pairs in the individual functional traits in order to identify traits exhibiting parallel responses. We identified traits exhibiting strong parallel response to the serpentine soil as those have a larger effect of the substrate of origin than the substrate of origin*population pair when grown in the selective serpentine soil (Fig. 2A, B). Regardless of the population pair, originally serpentine plants bolted earlier, had larger rosette area, higher number of additive rosettes, higher seed mass, higher root biomass, and lower uptake of $\mathrm{Ca}, \mathrm{Co}, \mathrm{Cr}, \mathrm{Mg}$, and $\mathrm{Ni}$ than non-serpentine plants when cultivated in serpentine soil (STable 6, Fig. 2A, B, SFig. 4).

On the contrary, we found only a minority of traits that showed rather non-parallel variation i.e. a dominant effect of the substrate of origin*population pair interaction: aboveground biomass, flowering time, and $\mathrm{Ca} / \mathrm{Mg}$ ratio in plants. The most remarkable difference was found for the $\mathrm{Ca} / \mathrm{Mg}$ ratio, where $\mathrm{S} 2$ and $\mathrm{S} 3$ populations accumulated relatively higher $\mathrm{Ca} / \mathrm{Mg}$ ratios than their paired $\mathrm{N}$ populations, while we observed a reverse trend in population pair 1 with lower (i.e. more skewed) values in S1 (Fig. 2C; as a consequence of the lower Ca uptake, Fig. S2). To test if such differences in $\mathrm{Ca} / \mathrm{Mg}$ uptake also correspond to non-parallel response to altered $\mathrm{Ca} / \mathrm{Mg}$ ratio in the environment, we cultivated plants of all populations in vitro on agar-solidified media with modified $\mathrm{Ca} / \mathrm{Mg}$ ratio and scored root growth and 
architecture. We observed consistently better root growth of originally serpentine over nonserpentine plants in highly skewed $\mathrm{Ca} / \mathrm{Mg}$ environments (Fig. 2D, E). In addition, lower $\mathrm{Ca} / \mathrm{Mg}$ ratio affected root architecture: serpentine plants had longer main roots and a lower density of lateral roots. Interestingly, such results were consistent over the three population pairs (Fig. 2D), suggesting that the specific pattern of $\mathrm{Ca}$ and $\mathrm{Mg}$ uptake of $\mathrm{S} 1$ population in serpentine soil is not mirrored in distinct fitness response to skewed $\mathrm{Ca} / \mathrm{Mg}$ concentrations per se and this population likely evolved a distinct mechanism how to cope with low $\mathrm{Ca} / \mathrm{Mg}$ ratio in its aboveground tissues.

Altogether, in line with expectations, the recently diverged serpentine populations exhibited pervasive phenotypic parallelism in functional traits in early as well as in later developmental stages with only a minority of traits showing non-parallel variation. 
bioRxiv preprint doi: https://doi.org/10.1101/2022.02.26.482078; this version posted February 26, 2022. The copyright holder for this preprint (which was not certified by peer review) is the author/funder. All rights reserved. No reuse allowed without permission.

A

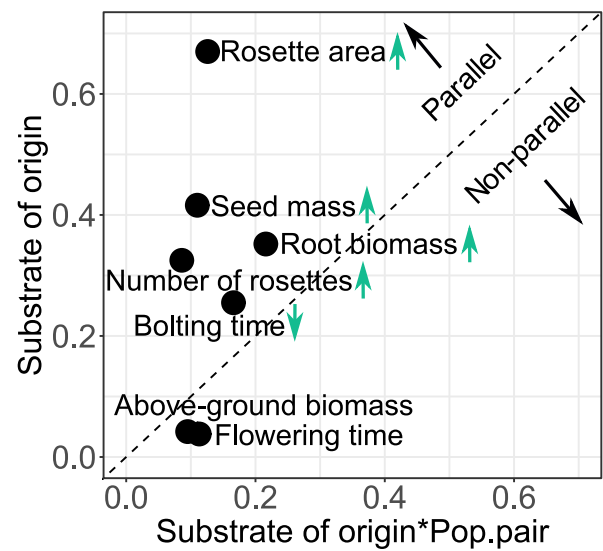

C

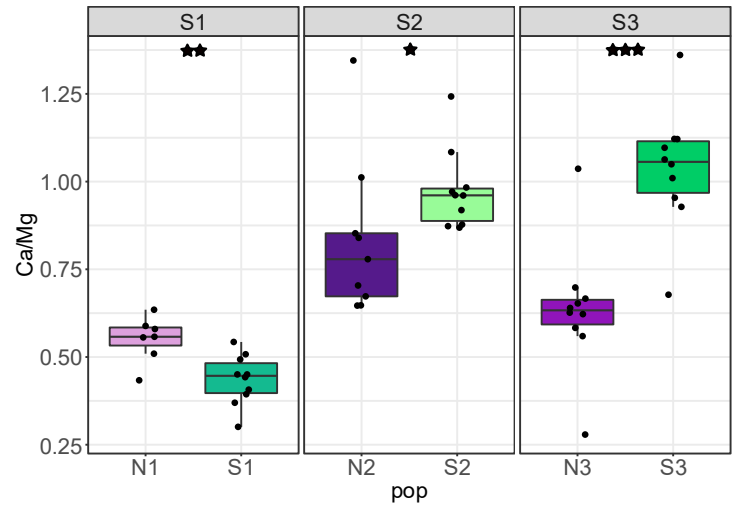

$\mathrm{E}$

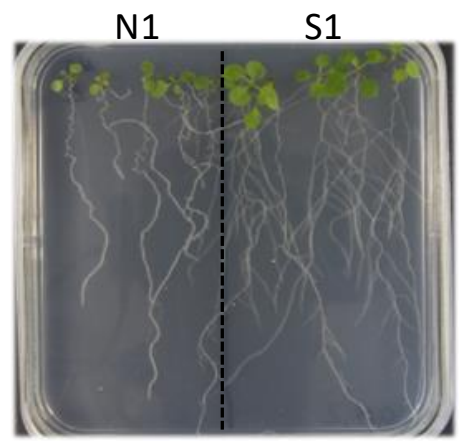

B

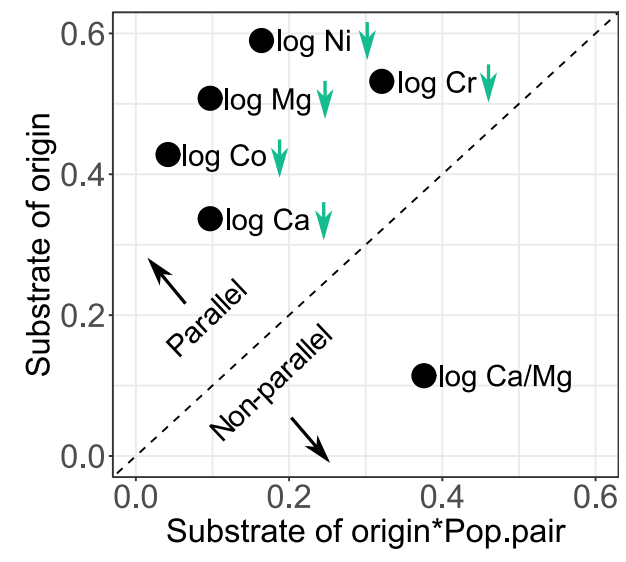

D
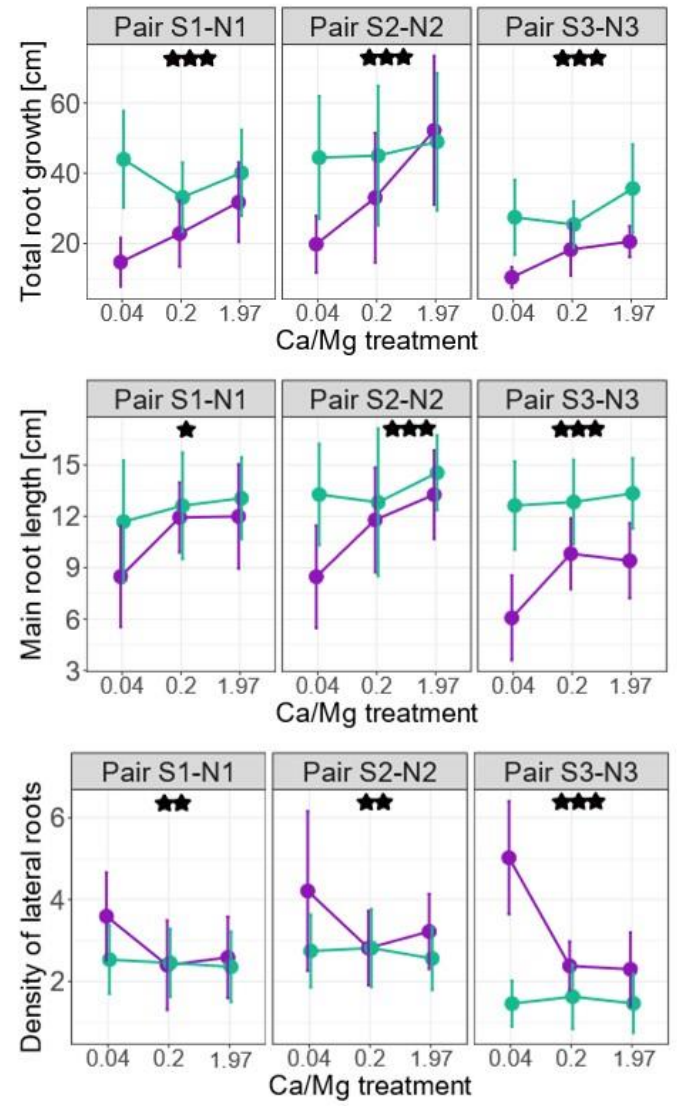

Fig. 2. Variation in the extent of parallelism among individual morphological life-history traits (A) and leaf elemental concentrations (B) scored on plants cultivated in the selective serpentine soils. The extent of parallelism was estimated as effect sizes (Eta2) in linear models addressing the effect of the substrate of origin (S vs. N), pop. pair $(1,2,3)$, and their interaction, calculated separately for each trait (see STable 7 for input values). The effect size of the substrate of origin (y-axis) shows the extent to which a given trait diverges predictably between serpentine and non-serpentine plants, i.e., in parallel, while the substrate of origin*population pair effect size (xaxis) quantifies the extent to which serpentine/non-serpentine phenotypic divergence varies across population pairs (i.e., deviates from parallel). Points falling above the dashed line have a larger substrate of origin effect (i.e. parallel) than the substrate of origin*pop. pair interaction effect (i.e. non-parallel). Green arrows indicate the overall trend in trait value in populations of serpentine origin. C) Variation in the ratio of $\mathrm{Ca} / \mathrm{Mg}$ content in the leaves of paired serpentine and non-serpentine populations cultivated in their corresponding serpentine soils. Note: asterisks denote the significance of the substrate of origin*treatment interaction $(* * * p<0.001 ; * * p<0.01 ; * p$ $<=0.05$; STable6). D) Differences in root growth of the three population pairs after 15 days since germination; note: 1.97 is a control medium, green: plants of serpentine origin, violet: plants of non-serpentine origin. Asterisks denote the significance of the effect of substrate of origin*treatment interaction $(* * * p<0.001 ; * * p<0.01 ; * p$ $<=0.05$ ). E) Illustrative photo from cultivation of $\mathrm{N} 1$ and $\mathrm{S} 1 \mathrm{plant}$ in $0.04 \mathrm{Ca} / \mathrm{Mg}$ treatment. 


\section{Genomic drivers of phenotypic parallelism}

To uncover the genetic architecture underlying the observed parallel phenotypes, we also quantified and characterized parallelism at the level of genes and functions. First, we took differentiation candidate genes (1\% outliers in $\mathrm{F}_{\mathrm{ST}}$ genetic differentiation between $\mathrm{S}$ and $\mathrm{N}$ populations; SData 1) identified by Konečná et al. (2021) for each pair and tested for gene-level parallelism. Although, we found a significant over-representation of shared genetic candidates across all combinations of population pairs (Fig. 3A; Fisher's exact test; $p<0.05$; SData 1), the proportion of shared candidate genes was rather low, ranging from $2.16 \%$ to $2.4 \%$ (Table S8).

A

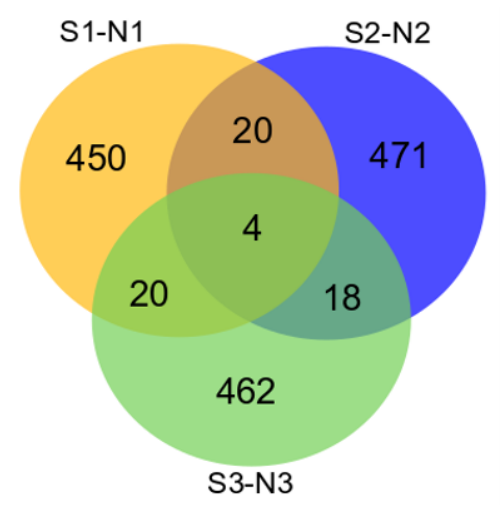

C iron ion homeostasis

ATG16310

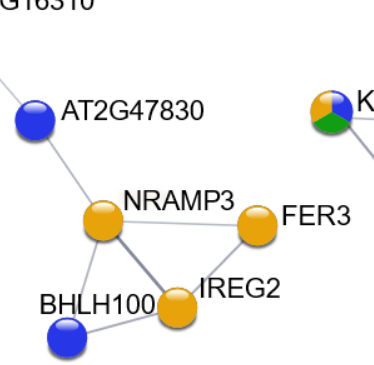

steroid biosynthetic process (stress hormones)

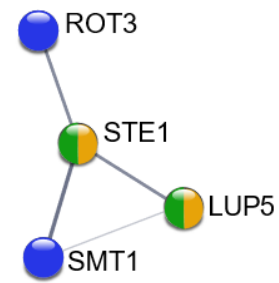

B

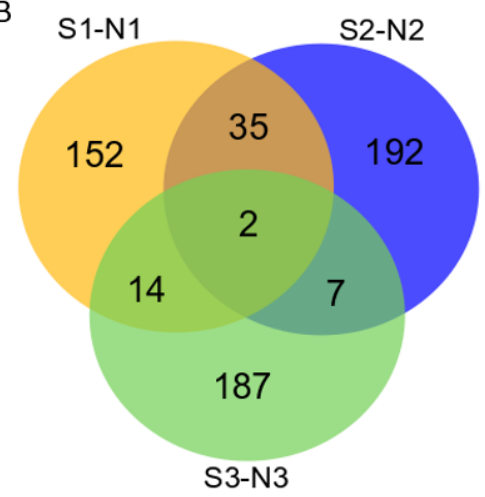

calcium ion binding inorganic cation transmembrane transport

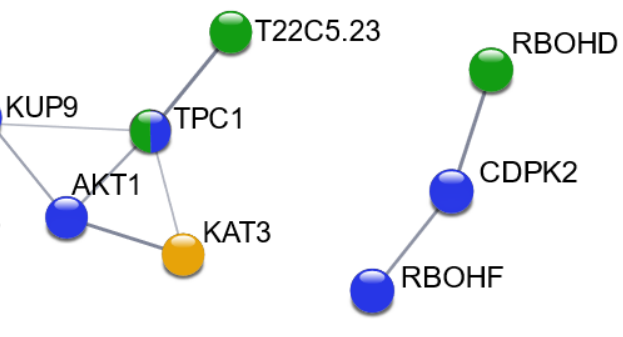

plant hormone signal transduction (osmotic stress)

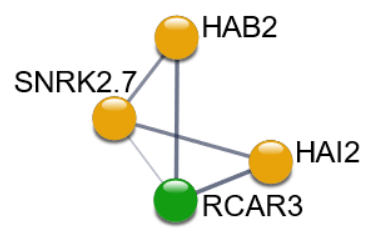

Fig. 3. Significant genomic parallelism among three investigated population pairs of A. arenosa. A) Intersection of differentiation candidate genes - parallelism by genes. B) Intersection of gene ontology terms in biological processes domain parallelism by function. The number of the overlapping items was significantly higher than random across all intersections $\quad(p<\quad 0.05$; Fisher's exact test; SData 1 and SData 2). C) Parallelism by function - significantly enriched biological processes or KEGG pathways extracted by STRING database; we used medium and higher confidence associations displayed by thickness of the lines (thick line is 0.4 and large line is 0.7 edge confidence). Note: colours are matching with part A) and B). Parallel differentiation candidates consist of multiple colours.

As the low gene-level parallelism might reflect genetic redundancy, we further associated all differentiation candidates with corresponding functional pathways (gene ontology - GO - enrichment analysis; SData 2) and quantified function-level parallelism (Fig. $3 \mathrm{~B})$ as the percentage of shared enriched GO terms between any two pairs of populations (STable 8). All overlaps were significant (Fisher's exact test; $p<0.05$, SData 2) and the extent of pairwise overlap ranged from $2.02 \%$ to $8.43 \%$ for the most relevant category of biological process (BP; similar results were also achieved for molecular functions, and cellular components; STable 8). We also observed significant functional parallelism even after removing the parallel differentiation candidates for GO enrichment analysis (STable 8). Significantly enriched BP in all three population pairs were cellular process and metabolic 
process. BP categories shared between two population pairs were more specific, reflecting multiple processes that are relevant for facing the toxic serpentine soils (Fig. 4): (i) cellular transport: transport (shared between S2-N2 and S3-N3), protein transport, protein localization, and organonitrogen compound metabolic process (all S1-N1 and S2-N2); (ii) abiotic stress: regulation of abscisic acid-activated signalling pathway, important in stress signalling (S1-N1 and S3-N3), response to endoplasmic reticulum stress (S1-N1 and S2-N2), and cellular response to stimulus (S1-N1 and S3-N3); and (iii) developmental processes: anatomical structure development (S1-N1 and S2-N2) and sexual sporulation (S1-N1 and S2-N2) (for complete lists see SData 2).

To further inspect function-level parallelism by a more specific pathway-oriented analyses, we inferred protein-protein functional networks from a combination of the differentiation candidates inferred for all three serpentine populations in STRING database. We found representative functional associations of distinct differentiation candidate genes inferred from different population pairs (Fig. 3C). For multiple functionally relevant parallel GO terms we showed that in each serpentine population, selection likely targeted different genes which belonged to the same pathway or developmental process. The STRING analysis also showed that candidate genes were highly inter-connected within such pathways (STable 9). Overall, we found significant parallelism by genes and functions associated with serpentine stress with evidence for selection on different genes from the same functional pathways possibly underlying the origin of functional parallel traits.

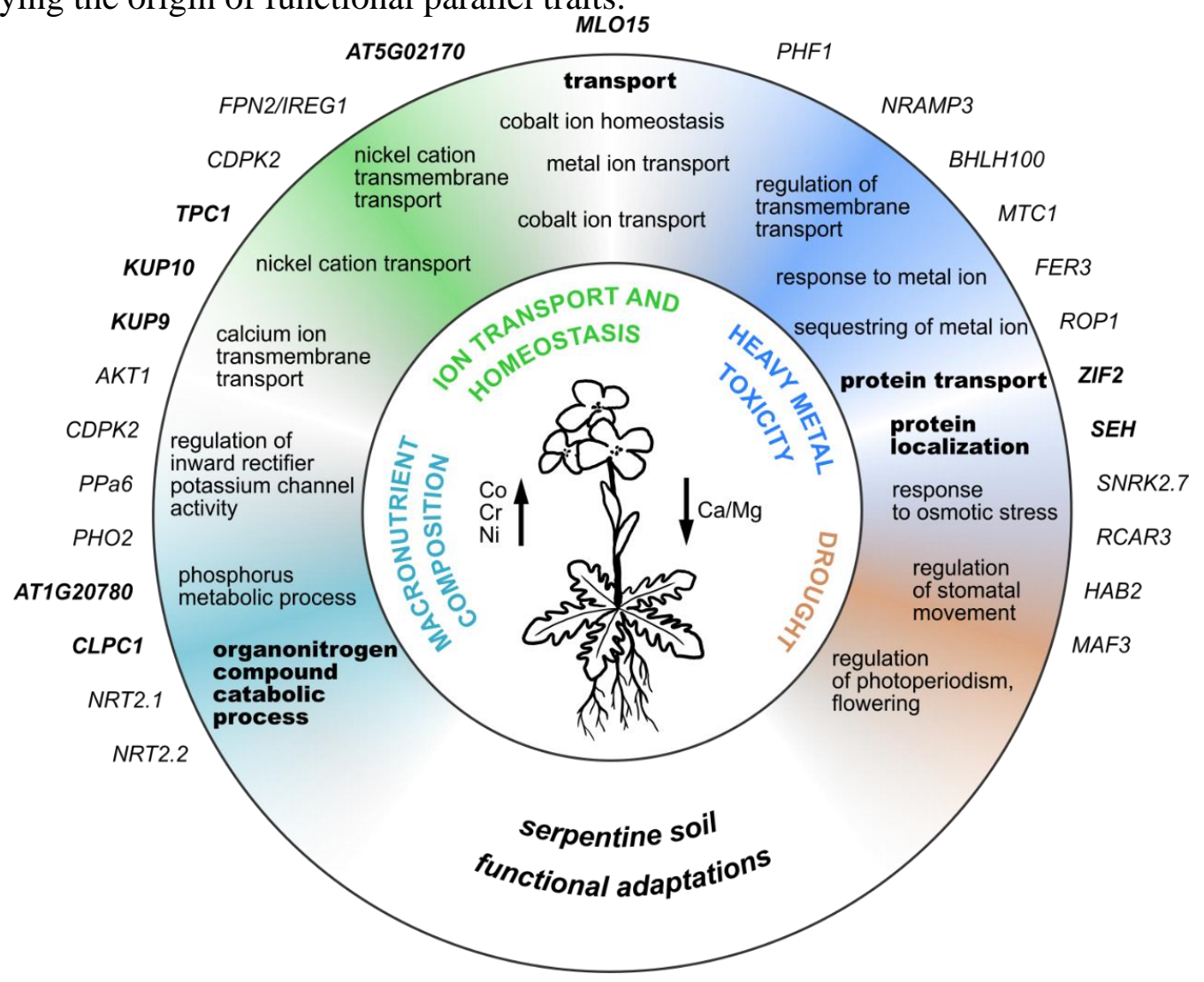

Fig. 4. Functional responses to the major environmental challenges of serpentine substrates detected by gene and functional pathway-level analysis of A. arenosa. The figure summarizes key serpentine-specific challenges following (Brady et al., 2005; O’Dell and Rajakaruna, 2011; Konečná et al., 2020), relevant significantly enriched biological process GO terms and differentiation candidate genes which were inferred for at least one (thin) and two/three (bold) serpentine populations. In the centre is an illustrative cartoon of the A. arenosa plant with phenotypic changes in line with serpentine adaptation detected in this study. Note: parallel genes and GO terms are in bold. 


\section{DISCUSSION}

\section{Varying magnitude of local adaptation and limited trade-offs}

Despite generally significant serpentine adaptation, the magnitude of fitness differences between originally serpentine and non-serpentine populations strikingly varied among the three population pairs, raising a question on the reason for such variation. Firstly, the overall difference in selective environment may determine strength of the selection and thus also the extent of phenotypic divergence; positive correlation between magnitude of local adaptation and environmental distance, although with the small effect, was shown already by metaanalyses (Hereford, 2009). Although the S3 - N3 population pair exhibited the largest magnitude of local adaptation and was also the most diverged based on substrate environmental distance, this was not true for population pair 2 with comparable substrate environmental distance, yet by far the smallest magnitude of local adaptation (Table 2). Secondly, neutral genetic differentiation, mirroring the extent of genetic divergence and intensity of gene flow, may indicate that population genomic processes play an important role (Savolainen et al., 2013). Indeed, the magnitude of local adaptation was always in congruence with the genome-wide differentiation within population pairs. It suggests that higher genetic differentiation between geographically proximal serpentine and non-serpentine populations results in a higher difference in fitness of plants cultivated in the serpentine soils (Fig. 1A, B). Although there was broad evidence for local serpentine adaptation (reviewed e.g. in Brady et al., 2005; Konečná et al., 2020), experimental cultivations were not accompanied by genetic investigations of population history. Systematic studies on a larger number of S-N population contrasts are needed to understand the relationship between genetic differentiation and magnitude of local adaptation.

Using various combinations of fitness proxies, we detected utmost limited trade-offs of serpentine adaptation, i.e. typically no cost of serpentine adaptation in non-serpentine soil. Limited cost of adaptation seems to be in congruence with a major trend in other studies summarized by Hereford (2009). Generally, adaptation trade-offs can rather evolve in homogeneous environment (e.g. in copper tolerance in Mimulus guttatus (Wright et al., 2013) than in heterogenous environment (Bono et al., 2017). For example, there was no difference in survival in non-serpentine sites between serpentine and non-serpentine M. guttatus (Selby and Willis, 2018) and only a little cost of adaptation was identified in serpentine Arabidopsis lyrata (Veatch-Blohm et al., 2017). Even in the pioneering serpentine reciprocal transplant experiments, Kruckeberg (1951) demonstrated the absence of trade-offs over various serpentine plants. He also proposed that the causes of trade-offs are related to the presence/absence of competition. Although, there is not much evidence to support this hypothesis (Sianta and Kay, 2019), in Helianthus exilis local serpentine adaptation was observed only without competition (Sambatti and Rice, 2006). Due to the absence of competitors in our experiments, we cannot rule out this explanation for the limited cost of adaptation. On the other hand, similar habitat types, generally low-competitive open mixed/coniferous forests with rocky outcrops, of serpentine vs. non-serpentine A. arenosa populations rather suggest comparable level of competition in both habitats.

\section{Pervasive phenotypic parallelism}

We detected parallel response to the selective serpentine substrate over the three independent serpentine populations in nearly all scored phenotypic traits (Fig. 2A, B). According to our expectations, in this recently diverged system encompassing postglacially adapted populations (Konečná et al., 2021), parallelism is largely manifested at the phenotypic level. The parallel traits, with larger effect size of the substrate of origin than the effect size of substrate of 
origin*population pair interaction, were prevailing - 10 out of 13 morphological life-history traits, fitness proxies, and traits related to ion uptake. Therefore, we showed that the phenotypic trait divergence between serpentine and non-serpentine populations seems to be largely predictable in A. arenosa. Experimental studies of serpentine adaptation revealed a range of life-history traits and physiological mechanisms showing similar responses among serpentine populations (e.g. Rajakaruna et al., 2003; Kolář et al., 2014), but also the variation in parallel traits depending on the similarity in the chemistry of the compared original serpentine soils (e.g. Berglund et al., 2004). The extent of parallelism was rarely studied and comprehensively quantified across multiple morphological and life-history traits, focusing mainly on animals (but see Knotek et al., 2020; James, Wilkinson, et al., 2021).

As specific soil chemistry is the principal selective factor of serpentines, regulation of micro-/macronutrients uptake and exclusion of heavy metals are expected to be the prime adaptive mechanisms (Brady et al., 2005; Kazakou et al., 2008). In line with this, serpentine adaptation in A. arenosa is likely dominantly driven by high levels of heavy metals (Co, $\mathrm{Cr}$, and $\mathrm{Ni}$ ), high concentration of $\mathrm{Mg}$, and low $\mathrm{Ca} / \mathrm{Mg}$ ratio, because concentration of these elements was consistently differentiating the original serpentine and non-serpentine soils (SFig. 1). Congruently, we found reduced uptake of all these elements in serpentine compared to nonserpentine plants when cultivated in serpentine soils, which was consistent across the three population pairs. Arabidopsis arenosa seems to reduce the uptake of heavy metals such as $\mathrm{Ni}$, similarly as has been shown for closely related A. lyrata (Veatch-Blohm et al., 2017) and some other species from the same geographic region such as Knautia arvensis group (Kolár et al., 2014). Importantly, response to the altered $\mathrm{Ca} / \mathrm{Mg}$ ratios, perhaps the most determining character of serpentines (Brady et al., 2005), has been observed already in the early life stages. We observed highly parallel trend of higher root growth of serpentine populations in media with highly skewed $\mathrm{Ca} / \mathrm{Mg}$ ratios, well supporting similar studies on serpentine ecotypes of some other species (Cerastium alpinum and K. arvensis; Berglund et al., 2004; Koláŕ et al., 2014) yet not universally (e.g. Galium valdepilosum; Kolář et al., 2013 and Streptanthus polygaloides; Boyd et al., 2009). Similarly to C. alpinum, also non-serpentine plants of A. arenosa had a higher number of lateral roots than serpentine plants. Different root growth strategies possibly evolved in serpentine populations as a response to high chemical stress the majority of resources are invested in the main root growth and the formation of lateral roots is down-regulated (Berglund et al., 2004). Furthermore, the highest difference in this trait was in population pair 3 , in which relevant differentiation candidate genes have been identified by a divergence scan (reduce lateral root formation $(R L F)$, repressor of lateral root initiation (NRT2.1); SData 1) suggesting genetic basis of such trait.

\section{Causes and consequences of non-parallel phenotypes}

Despite the generally dominant phenotypic parallelism, we observed regionally specific patterns in three traits: above-ground biomass, flowering time and varying $\mathrm{Ca} / \mathrm{Mg}$ ratio in leaves. Besides that, the non-parallelism was also observed in the germination rate in serpentine soils in a previous study by Konečná et al. (2021). While N2 and N3 populations had $93 \%$ and $86 \%$ germination rates, the N1 population did not germinate at all in serpentine soil (Konečná et al., 2021). Such locally-specific responses may reflect a complex interplay of the genetic basis of traits, genetic drift, and local environmental heterogeneity (Rosenblum et al., 2014; Fraïsse and Welch, 2019; James, Wilkinson, et al., 2021). In the case of leaf $\mathrm{Ca} / \mathrm{Mg}$ ratio, S2 and $\mathrm{S} 3$ populations had relatively higher leaf $\mathrm{Ca} / \mathrm{Mg}$ ratios than proximal non-serpentine populations, yet the opposite was observed for S1-N1 population pair. Highly skewed $\mathrm{Ca} / \mathrm{Mg}$ ratio $(<1)$ is the major factor defying serpentines worldwide (O’Dell and Rajakaruna, 2011) and the importance of $\mathrm{Ca}$ availability in the light of increased $\mathrm{Mg}$ has been highlighted for almost a century (Novák, 1928; Vlamis and Jenny, 1948; Vlamis, 1949; Kruckeberg, 1954; Walker et 
al., 1955). For instance, adapted serpentine populations of $A$. millefolium had higher leaf $\mathrm{Ca} / \mathrm{Mg}$ ratio than non-serpentine plants suggesting root to shoot transfer of calcium, selective uptake of $\mathrm{Ca}$, or exclusion of $\mathrm{Mg}$ (O'Dell and Claassen, 2006). Variation in leaf $\mathrm{Ca} / \mathrm{Mg}$ ratio among serpentine A. lyrata populations has been also shown by Veatch-Blohm et al. (2013). In A. arenosa, reduced uptake of $\mathrm{Mg}$ seems to be an important mechanism how to regulate the $\mathrm{Ca} / \mathrm{Mg}$ ratio in serpentine plants (SFig. 4). Levels of $\mathrm{Ca}^{2+}$ cations in the cells are controlled by an array of channels and carriers pointing to the complex genetic basis of Ca homeostasis and signalling (Tang and Luan, 2017). Interestingly, one of the parallel differentiation candidate genes encoding central calcium channel and mediating stress signalling - TPCl (Choi et al., 2014) appeared as a selection candidate in population pairs 2 and 3, but not in pair 1 (Konečná et al., 2021) suggesting that observed non-parallelism may have a genetic basis.

Other non-parallel trait was flowering time, which was a subject of many studies on serpentine adaptation. The selection for flowering shifts with genetic basis has been shown in various taxa adapted to serpentine soils in California (Sianta and Kay, 2019). Sianta and Kay (2021) also showed that colonization of serpentine sites can cause maladaptive shifts to later flowering in the early stages of divergence. Indeed, this is in congruence with observations in A. arenosa, where we observed later flowering in the S2 population than in the N2 population, i.e. in the population pair exhibiting the most recent divergence time (Konečná et al., 2021). Although earlier flowering in serpentine plants was documented in many species, for instance in Solidago virgaurea (Sakaguchi et al., 2017), Picris hieracioides (Sakaguchi et al., 2018), and Helianthus exilis (Sambatti and Rice, 2006), Sianta and Kay (2021) showed shifts to later flowering in serpentine taxa. This is in high contrast to the general paradigm that serpentine adapted plants flower early to escape the drought in rocky serpentine sites in summer (Brady et al., 2005; Ferris and Willis, 2018). Such mixed evidence for plant earlier vs. later flowering in serpentine compared to non-serpentine populations is thus recapitulated also in our dataset and we hypothesize it might be due to variation among serpentine habitats. In particular, the S3 population with the earliest flowering time occupies the south-facing rocky outcrops that are most likely candidates for a selective extreme habitat affected by summer drought.

\section{Genetic redundancy and polygenic architecture underlying observed parallelism}

We observed significant gene parallelism but affecting a relatively low number of genes (ranging from $2.16 \%$ to $2.4 \%$ ). It is rather surprising given the large pool of variation shared in this polyploid and recently diverged system (Konečná et al., 2021). However, it is consistent with an array of other studies showing similar levels of parallelism (Lai et al., 2019; Preite et al., 2019; Ji et al., 2020; Bohutínská et al., 2021; James, Wilkinson, et al., 2021; Papadopulos et al., 2021). Although, possibly high number of false-positive candidates resulting from $\mathrm{F}_{\mathrm{ST}}$ scans can lead to a decrease in the percentage of parallels. This extent of parallelism corresponds with genetic redundancy and polygenic architecture of serpentine adaptation.

Relative low number of shared differentiation candidate genes can also reflect relatively simple genetic architecture of serpentine adaptation that is driven by only a few high-effect genes. Although this seems to be indeed the case for several serpentine plants (Silene, Mimulus; (Bratteler et al., 2006; Selby and Willis, 2018)), it is likely not the case of Arabidopsis. Polygenic basis of serpentine adaptation, i.e. allele frequency shifts in many genes across population pairs (Yeaman, 2015; Wilkinson et al., 2021), has been previously identified by high-density divergence scans for selection in A. arenosa and A. lyrata (Turner et al., 2010; Arnold et al., 2016; Konečná et al., 2021). These studies showed that many loci with small effects are often under selection when facing complex even well-defined environmental challenges. In contrast, evidence for simple genetic architecture is typically based on quantitative trait locus (QTL) studies, such as Ni tolerance in Silene vulgaris and Caulanthus amplexicaulis (Bratteler et al., 2006; Burrell et al., 2012) and survival of Mimulus guttatus 
(Selby and Willis, 2018). Importantly, QTL studies are usually biased to detect major-effect loci thus providing limited insights into polygenic adaptations.

We also observed similarity in functional pathways, moreover, many of which were corresponding to observed parallel phenotypic differences in iron ion homeostasis, inorganic cation transmembrane transport, steroid biosynthetic process; molecular functions of calcium ion binding; and KEGG pathway (Kanehisa and Goto, 2000) of plant hormone signal transduction (Fig. 3C and Fig. 4 for other functional pathways). Importantly, significant overlaps in such GO terms remained even if parallel gene candidates were excluded, demonstrating selection on different genes in similar functional pathways and developmental processes. This shows the important role of genetic redundancy in rapid adaptations with polygenic basis (Boyle et al., 2017; Barghi et al., 2020; Láruson et al., 2020). That genetic redundancy as important factor underlying parallel adaptation towards complex environmental challenges has been also shown in other systems such as in alpine Heliosperma pusillum (Trucchi et al., 2017; Szukala et al., 2021) or dune Senecio lauttus (James, Allsopp, et al., 2021), but also from more narrowly defined environments - metal-polluted mines in Silene uniflora (Papadopulos et al., 2021) or temperature adaptations in Drosophila simulans (Barghi et al., 2019). In summary, given the expected polygenic basis of adaptation, it is unlikely that limited gene-level parallelism simply reflects genetic architecture but rather represent a combined effect of genetic redundancy and potential technical limitations of selection scans (e.g. increased rates of single-region false positives and limits in the detection of soft sweeps (Hoban et al., 2016)).

\section{Conclusions}

Here we document overall parallel response to serpentine substrate across a diversity of functional traits with utmost very limited trade-offs. Repeatedly identified enrichment of multiple relevant functional pathways, despite rather modest gene-level parallelism, demonstrates the complex interplay of allele sharing, likely polygenic architecture of the adaptation, and genetic redundancy underlies the observed parallel phenotypic manifestation of serpentine adaptation. Despite this general trend, there are also certain population- and traitspecific non-parallel deviations likely reflecting rather differences in genetic processes than variation in selective effect of the local environments. Further investigations of the genotypephenotype links in well-defined strongly selective environments, such as serpentines, will help us to better assess the role of genetic redundancy in polygenic systems and its impact on the extent of parallelism in adaptation and thus evolutionary predictability.

\section{Conflict of interest}

The authors declare no conflict of interest.

\section{Author contributions}

V.K. and F.K. conceived the study. V.K., F.K., M.C., E.T., and M.S. designed experiments. V.K. and M.C. did field collections. A.K. performed the laboratory analyses. V.K., D.P. and M.S. performed the experiments. V.K. and D.P. performed data analyses. V.K. and F.K. wrote the manuscript with input from all authors.

\section{Acknowledgements}

This work was supported by Charles University (project Primus/SCI/35 to F.K. and the Grant Agency of Charles University project No. 410120 to V.K.) and the European Research Council (ERC) under the European Union's Horizon 2020 research and innovation programme [ERCStG 850852 DOUBLE ADAPT to F.K.]. Additional support was provided by the long-term 
bioRxiv preprint doi: https://doi.org/10.1101/2022.02.26.482078; this version posted February 26, 2022. The copyright holder for this preprint (which was not certified by peer review) is the author/funder. All rights reserved. No reuse allowed without permission.

research development project No. RVO 67985939 of the Czech Academy of Sciences. Computational resources were provided by the CESNET LM2015042 and the CERIT Scientific Cloud LM2015085. The authors thank Petr Knotek, Tereza Holcová, Veronika Vlčková, Eliška Konečná, Barbora Lepková, Timothée Lamotte, and Karolína Havlíková for help with field work, experiments, data collection and laboratory work.

\section{REFERENCES}

Alexa, A., and J. Rahnenfuhrer. 2020. topGO: Enrichment Analysis for Gene Ontology. R package version 2.42.0.

Arnold, B. J., B. Lahner, J. M. DaCosta, C. M. Weisman, J. D. Hollister, D. E. Salt, K. Bomblies, and L. Yant. 2016. Borrowed alleles and convergence in serpentine adaptation. Proceedings of the National Academy of Sciences 113: 8320-8325.

Barghi, N., J. Hermisson, and C. Schlötterer. 2020. Polygenic adaptation: a unifying framework to understand positive selection. Nature Reviews Genetics 21: 769-781.

Barghi, N., R. Tobler, V. Nolte, A. M. Jaksic, F. Mallard, K. A. Otte, M. Dolezal, et al. 2019. Polygenic adaptation fuels genetic redundancy in Drosophila. PLoS Biology 17: 1-31.

Berglund, A. N., S. Dahlgren, and A. Westerbergh. 2004. Evidence for parallel evolution and site-specific selection of serpentine tolerance in Cerastium alpinum during the colonization of Scandinavia. New Phytologist 161: 199-209.

Bohutínská, M., J. Vlček, S. Yair, B. Leanen, V. Konečná, M. Fracassetti, T. Slotte, and F. Kolář. 2021. Genomic basis of parallel adaptation varies with divergence in Arabidopsis and its relatives. Proceedings of the National Academy of Sciences 118: e2022713118.

Bolnick, D. I., R. D. H. Barrett, K. B. Oke, D. J. Rennison, and Y. E. Stuart. 2018. (Non) Parallel Evolution. Annual Review of Ecology, Evolution, and Systematics 49: 303-330.

Bono, L. M., L. B. Smith, D. W. Pfennig, and C. L. Burch. 2017. The emergence of performance trade-offs during local adaptation: insights from experimental evolution. Molecular Ecology 26: 1720-1733.

Boyd, R. S., M. A. Wall, S. R. Santos, and M. A. Davis. 2009. Variation of Morphology and Elemental Concentrations in the California Nickel Hyperaccumulator Streptanthus polygaloides (Brassicaceae) . Northeastern Naturalist 16: 21-38.

Boyle, E. A., Y. I. Li, and J. K. Pritchard. 2017. An Expanded View of Complex Traits: From Polygenic to Omnigenic. Cell 169: 1177-1186.

Bradshaw, H. D. 2005. Mutations in CAX1 produce phenotypes characteristic of plants tolerant to serpentine soils. New Phytologist 167: 81-88.

Brady, K. U., A. R. Kruckeberg, and H. D. Bradshaw Jr. 2005. Evolutionary Ecology of Plant Adaptation to Serpentine Soils. Annual Review of Ecology, Evolution, and Systematics 36: 243-266.

Bratteler, M., M. Baltisberger, and A. Widmer. 2006. QTL analysis of intraspecific differences between two Silene vulgaris ecotypes. Annals of Botany 98: 411-419.

Burrell, M. A., A. K. Hawkins, and A. E. Pepper. 2012. Genetic analyses of nickel tolerance in a North American serpentine endemic plant, Caulanthus amplexicaulis var. barbarae (Brassicaceae). American Journal of Botany 99: 1875-1883.

Choi, W. G., M. Toyota, S. H. Kim, R. Hilleary, and S. Gilroy. 2014. Salt stress-induced Ca2+ waves are associated with rapid, long-distance root-to-shoot signaling in plants. Proceedings of the National Academy of Sciences of the United States of America 111: 6497-6502.

Fang, B., P. Kemppainen, P. Momigliano, and J. Merilä. 2021. Population Structure Limits Parallel Evolution in Sticklebacks. Molecular Biology and Evolution 38: 4205-4221.

Ferris, K. G., and J. H. Willis. 2018. Differential adaptation to a harsh granite outcrop habitat between sympatric Mimulus species. Evolution 72: 1225-1241.

Fraïsse, C., and J. J. Welch. 2019. The distribution of epistasis on simple fitness landscapes. Biology Letters 15: 20180881.

Geyer, C. J., S. Wagenius, and R. G. Shaw. 2007. Aster models for life history analysis. Biometrika 94: 415426.

Hämälä, T., and O. Savolainen. 2019. Genomic patterns of local adaptation under gene flow in Arabidopsis lyrata. Molecular Biology and Evolution 36: 2557-2571.

Hereford, J. 2009. A quantitative survey of local adaptation and fitness trade-offs. American Naturalist 173: 579-588.

Hermisson, J., and P. S. Pennings. 2017. Soft sweeps and beyond: understanding the patterns and probabilities of selection footprints under rapid adaptation. Methods in Ecology and Evolution 8: 700-716.

Hoban, S., J. L. Kelley, K. E. Lotterhos, M. F. Antolin, G. Bradburd, D. B. Lowry, M. L. Poss, et al. 2016. 
bioRxiv preprint doi: https://doi.org/10.1101/2022.02.26.482078; this version posted February 26, 2022. The copyright holder for this preprint (which was not certified by peer review) is the author/funder. All rights reserved. No reuse allowed without permission.

Finding the Genomic Basis of Local Adaptation: Pitfalls, Practical Solutions, and Future Directions. The American naturalist 188: 379-397.

Höllinger, I., P. S. Pennings, and J. Hermisson. 2019. Polygenic adaptation: From sweeps to subtle frequency shifts. PLoS Genetics 15: 1-26.

Jacobs, A., M. Carruthers, A. Yurchenko, N. V. Gordeeva, S. S. Alekseyev, O. Hooker, J. S. Leong, et al. 2020. Parallelism in eco-morphology and gene expression despite variable evolutionary and genomic backgrounds in a Holarctic fish. PLoS Genetics 16: e1008658.

James, M. E., R. N. Allsopp, J. S. Groh, K. Avneet, M. J. Wilkinson, and D. Ortiz-Barrientos. 2021. Uncovering the genetic architecture of replicated adaptation. SSRN preprint. 3981902.

James, M. E., H. Arenas-Castro, J. S. Groh, S. L. Allen, J. Engelstädter, and D. Ortiz-Barrientos. 2021. Highly Replicated Evolution of Parapatric Ecotypes. Molecular Biology and Evolution 38: 4805-4821.

James, M. E., M. J. Wilkinson, D. M. Bernal, H. Liu, H. L. North, J. Engelstädter, and D. Ortiz-Barrientos. 2021. Phenotypic and genotypic parallel evolution in parapatric ecotypes of Senecio. Evolution 75: 3115-3131.

Ji, Y., X. Li, T. Ji, J. Tang, L. Qiu, J. Hu, J. Dong, et al. 2020. Gene reuse facilitates rapid radiation and independent adaptation to diverse habitats in the Asian honeybee. Science Advances 6: eabd3590.

Kanehisa, M., and S. Goto. 2000. KEGG: kyoto encyclopedia of genes and genomes. Nucleic acids research 28: 27-30.

Kazakou, E., P. G. Dimitrakopoulos, A. J. M. Baker, R. D. Reeves, and A. Y. Troumbis. 2008. Hypotheses , mechanisms and trade-offs of tolerance and adaptation to serpentine soils: from species to ecosystem level. 495-508.

Knotek, A., V. Konečná, G. Wos, D. Požárová, G. Šrámková, M. Bohutínská, V. Zeisek, et al. 2020. Parallel Alpine Differentiation in Arabidopsis arenosa. Frontiers in Plant Science 11: 561526.

Kolář, F., M. Dortová, J. Lepš, M. Pouzar, and A. Krejčová. 2014. Serpentine ecotypic differentiation in a polyploid plant complex: shared tolerance to $\mathrm{Mg}$ and $\mathrm{Ni}$ stress among di- and tetraploid serpentine populations of. Plant and Soil 374: 435-447.

Kolář, F., M. Lučanová, P. Vít, T. Urfus, J. Chrtek, T. Fér, F. Ehrendorfer, and J. Suda. 2013. Diversity and endemism in deglaciated areas: Ploidy, relative genome size and niche differentiation in the Galium pusillum complex (Rubiaceae) in Northern and Central Europe. Annals of Botany 111: 1095-1108.

Konečná, V., S. Bray, J. Vlček, M. Bohutínská, D. Požárová, R. R. Choudhury, A. Bollmann-Giolai, et al. 2021. Parallel adaptation in autopolyploid Arabidopsis arenosa is dominated by repeated recruitment of shared alleles. Nature Communications 12: 4979.

Konečná, V., L. Yant, and F. Kolář. 2020. The Evolutionary Genomics of Serpentine Adaptation. Frontiers in Plant Science 11: 574616.

Kruckeberg, A. R. 1951. Intraspecific Variability in the Response of Certain Native Plant Species to Serpentine Soil. American Journal of Botany 38: 408-419.

Kruckeberg, A. R. 1954. The ecology of serpentine soils: A symposium. III. Plant species in relation to serpentine soils. Ecology 35: 267-74.

Lai, Y. T., C. K. L. Yeung, K. E. Omland, E. L. Pang, Y. Hao, B. Y. Liao, H. F. Cao, et al. 2019. Standing genetic variation as the predominant source for adaptation of a songbird. Proceedings of the National Academy of Sciences of the United States of America 116: 2152-2157.

Láruson, Á. J., S. Yeaman, and K. E. Lotterhos. 2020. The Importance of Genetic Redundancy in Evolution. Trends in Ecology and Evolution 35: 809-822.

Lenormand, T., D. Roze, and F. Rousset. 2009. Stochasticity in evolution. Trends in Ecology and Evolution 24: $157-165$.

Magalhaes, I. S., J. R. Whiting, D. D’Agostino, P. A. Hohenlohe, M. Mahmud, M. A. Bell, S. Skúlason, and A. D. C. MacColl. 2021. Intercontinental genomic parallelism in multiple three-spined stickleback adaptive radiations. Nature Ecology and Evolution 5: 251-261.

Morales, H. E., R. Faria, K. Johannesson, T. Larsson, M. Panova, A. M. Westram, and R. K. Butlin. 2019. Genomic architecture of parallel ecological divergence: Beyond a single environmental contrast. Science Advances 5: eaav9963.

Novák, F. A. 1928. Quelques remarques relatives au probleme de la vegetation sur les terrains serpentinques. Preslia 6: 42-71.

O’Dell, R. E., and V. P. Claassen. 2006. Serpentine and nonserpentine Achillea millefolium accessions differ in serpentine substrate tolerance and response to organic and inorganic amendments. Plant and Soil 279: 253-269.

O’Dell, R. E., and N. Rajakaruna. 2011. Intraspecific variation, adaptation, and evolution. In S. Harrison, and N. Rajakaruna [eds.], Serpentine: Evolution and ecology in a model system, 97-137. University of California Press.

Papadopulos, A. S. T., A. J. Helmstetter, O. G. Osborne, A. A. Comeault, D. P. Wood, E. A. Straw, L. Mason, et al. 2021. Rapid Parallel Adaptation to Anthropogenic Heavy Metal Pollution. Molecular Biology and 
bioRxiv preprint doi: https://doi.org/10.1101/2022.02.26.482078; this version posted February 26, 2022. The copyright holder for this

Evolution 38: 3724-3736.

Preite, V., C. Sailer, L. Syllwasschy, S. Bray, U. Kraemer, and L. Yant. 2019. Convergent evolution in Arabidopsis halleri and Arabidopsis arenosa on calamine metalliferous soils. Philosophical Transactions of the Royal Society B 374: 20180243.

Rajakaruna, N., M. Y. Siddiqi, J. Whitton, B. A. Bohm, and A. D. M. Glass. 2003. Differential responses to $\mathrm{Na}+/ \mathrm{K}+$ and $\mathrm{Ca} 2+/ \mathrm{Mg} 2+$ in two edaphic races of the Lasthenia californica (Asteraceae) complex: A case for parallel evolution of physiological traits. New Phytologist 157: 93-103.

Rosenblum, E. B., C. E. Parent, and E. E. Brandt. 2014. The Molecular Basis of Phenotypic Convergence. Annual Review of Ecology, Evolution, and Systematics 45: 203-226.

Sakaguchi, S., K. Horie, N. Ishikawa, A. J. Nagano, M. Yasugi, H. Kudoh, and M. Ito. 2017. Simultaneous evaluation of the effects of geographic, environmental and temporal isolation in ecotypic populations of Solidago virgaurea. New Phytologist 216: 1268-1280.

Sakaguchi, S., K. Horie, T. Kimura, A. J. Nagano, Y. Isagi, and M. Ito. 2018. Phylogeographic testing of alternative histories of single-origin versus parallel evolution of early flowering serpentine populations of Picris hieracioides L. (Asteraceae) in Japan. Ecological Research 33: 537-547.

Salmón, P., A. Jacobs, D. Ahrén, C. Biard, N. J. Dingemanse, D. M. Dominoni, B. Helm, et al. 2021. Continentwide genomic signatures of adaptation to urbanisation in a songbird across Europe. Nature Communications 12: 2983.

Sambatti, J. B. M., and K. J. Rice. 2006. Local adaptation, patterns of selection, and gene flow in the Californian serpentine sunflower (Helianthus exilis). Evolution 60: 696-710.

Savolainen, O., M. Lascoux, and J. Merilä. 2013. Ecological Genomics: genes in ecology and ecology in genes. Nature Reviews Genetics 14: 807-820.

Schmickl, R., J. Paule, J. Klein, K. Marhold, and M. A. Koch. 2012. The evolutionary history of the Arabidopsis arenosa complex: Diverse tetraploids mask the Western Carpathian center of species and genetic diversity. PLOS ONE 7: e42691.

Selby, J. P., and J. H. Willis. 2018. Major QTL controls adaptation to serpentine soils in Mimulus guttatus. Molecular Ecology 27: 5073-5087.

Shaw, R. G., C. J. Geyer, S. Wagenius, H. H. Hangelbroek, and J. R. Etterson. 2008. Unifying life-history analyses for inference of fitness and population growth. American Naturalist 172: E35-E47.

Sianta, S. A., and K. M. Kay. 2019. Adaptation and divergence in edaphic specialists and generalists: serpentine soil endemics in the California flora occur in barer serpentine habitats with lower soil calcium levels than serpentine tolerators. American Journal of Botany 106: 690-703.

Sianta, S. A., and K. M. Kay. 2021. Parallel evolution of phenological isolation across the speciation continuum in serpentine-adapted annual wildflowers. Proceedings of the Royal Society B: Biological Sciences 288 : 20203076.

Stuart, Y. E., T. Veen, J. N. Weber, D. Hanson, M. Ravinet, B. K. Lohman, C. J. Thompson, et al. 2017. Contrasting effects of environment and genetics generate a continuum of parallel evolution. Nature Ecology and Evolution 1: 1-7.

Szklarczyk, D., A. Franceschini, S. Wyder, K. Forslund, D. Heller, J. Huerta-Cepas, M. Simonovic, et al. 2015. STRING v10: Protein-protein interaction networks, integrated over the tree of life. Nucleic Acids Research 43: D447-D452.

Szukala, A., J. Lovegrove-Walsh, H. Luqman, S. Fior, T. Wolfe, B. Frajman, P. Schönswetter, and O. Paun. 2021. Polygenic routes lead to parallel altitudinal adaptation in. bioRxiv: 2021.07.05.451094.

Tang, R., and S. Luan. 2017. Regulation of calcium and magnesium homeostasis in plants: from transporters to signaling network. Current Opinion in Plant Biology 39: 97-105.

Trucchi, E., B. Frajman, T. H. A. Haverkamp, P. Schönswetter, and O. Paun. 2017. Genomic analyses suggest parallel ecological divergence in Heliosperma pusillum (Caryophyllaceae). New Phytologist 216: $267-278$.

Turner, T. L., E. C. Bourne, E. J. Von Wettberg, T. T. Hu, and S. V Nuzhdin. 2010. Population resequencing reveals local adaptation of Arabidopsis lyrata to serpentine soils. Nature Genetics 42: 260-263.

Veatch-Blohm, M. E., B. M. Roche, and M. J. Campbell. 2013. Evidence for Cross-Tolerance to Nutrient Deficiency in Three Disjunct Populations of Arabidopsis lyrata ssp. lyrata in Response to Substrate Calcium to Magnesium Ratio. PLoS ONE 8: e63117.

Veatch-Blohm, M. E., B. M. Roche, and E. E. Dahl. 2017. Serpentine populations of Arabidopsis lyrata ssp. lyrata show evidence for local adaptation in response to nickel exposure at germination and during juvenile growth. Environmental and Experimental Botany 138: 1-9.

Vlamis, J. 1949. Growth of Lettuce and Barley As Influenced By Degree of Calcium-Saturation of Soil. Soil Science 67: 453-466.

Vlamis, J., and H. Jenny. 1948. Calcium deficiency in serpentine soils as revealed by adsorbent technique. Science 107: 549. 
bioRxiv preprint doi: https://doi.org/10.1101/2022.02.26.482078; this version posted February 26, 2022. The copyright holder for this preprint (which was not certified by peer review) is the author/funder. All rights reserved. No reuse allowed without permission.

Walker, R. B., M. Walker, Helene, and P. Ashworth. 1955. Calcium-magnesium nutrition with special reference to serpentine soils. Plant Physiology 30: 214.

Wang, M., Y. Zhao, and B. Zhang. 2015. Efficient Test and Visualization of Multi-Set Intersections. Scientific Reports 5: 1-12.

Weber, A. A. T., J. Rajkov, K. Smailus, B. Egger, and W. Salzburger. 2021. Speciation dynamics and extent of parallel evolution along a lake-stream environmental contrast in African cichlid fishes. Science Advances 7: $1-21$.

Whiting, J. R., J. R. Paris, M. J. van der Zee, P. J. Parsons, D. Weigel, and B. A. Fraser. 2021. Drainagestructuring of ancestral variation and a common functional pathway shape limited genomic convergence in natural high- And low-predation guppies. PLoS Genetics 17: 1-29.

Wilkinson, M. J., F. Roda, G. M. Walter, M. E. James, R. Nipper, J. Walsh, S. L. Allen, et al. 2021. Adaptive divergence in shoot gravitropism creates hybrid sterility in an Australian wildflower. Proceedings of the National Academy of Sciences of the United States of America 118: 1-11.

Wright, K. M., D. Lloyd, D. B. Lowry, M. R. Macnair, and J. H. Willis. 2013. Indirect Evolution of Hybrid Lethality Due to Linkage with Selected Locus in Mimulus guttatus. PLoS Biology 11: e1001497.

Yeaman, S. 2015. Local adaptation by alleles of small effect. American Naturalist 186: S74-S89.

Zbíral, J., E. Čižmárová, E. Obdržálková, M. Rychlý, V. Vilamová, J. Srnková, and A. Žalmanová. 2016. Jednotné pracovní postupy: Analýza půd I. Ústřední kontrolní a zkušební ústav zemědělský. 


\section{SUPPLEMENTARY METHODS}

\section{Reciprocal transplant experiment}

We germinated seeds from 12 mother plants (each representing a seed family of a mixture of full- and half-sibs) from each population in Petri dishes filled by either type of soil (15 seeds/family/treatment). Seeds germinated in the growth chamber (Conviron) under conditions approximating spring season at the original sites: $12 \mathrm{~h}$ dark at $10^{\circ} \mathrm{C}$ and $12 \mathrm{~h}$ light at $20^{\circ} \mathrm{C}$. Due to zero germination of N1 seeds in S1 soil, we measured differential growth response on plants that were germinated in the non-serpentine soils and were subjected to the differential soil treatment later, in a seedling stage. We chose $44-50$ seedlings equally representing progeny of 11 maternal plants per each population (in total 284 seedlings), transferred each plant to a separate pot filled either with $\sim 1 \mathrm{~L}$ of the original or the alternative paired soil (i.e. S1 soil for N1 population and vice versa). We randomly swapped the position of each pot twice a week and watered them with tap water when needed. The germination rates were published in Konečná et al. (2021).

\section{Elemental analysis of soil and leaf samples}

Determination of $\mathrm{Ca}, \mathrm{Co}, \mathrm{Cr}, \mathrm{Mg}$, and $\mathrm{Ni}$ in plant tissues of A. arenosa and soil samples was carried out using inductively coupled plasma optical emission spectrometry (ICP OES).

Due to very small amounts of leaf samples in units to tens of $\mathrm{mg}$, the samples were decomposed prior to the analysis using the microwave oven Speedwave $®$ Xpert (Berghof, Germany, maximal applied power $2000 \mathrm{~W}$ ) with a multi-tube system. The plant tissue (2 replicates, $8-50 \mathrm{mg}$ according to the available sample amount) was inserted into digestion tubes and treated with $2 \mathrm{ml}$ of sub boilingly distilled (Berghof, Germany) nitric acid (Lachner, the Czech Republic) under the following conditions: 10 min hold on $170{ }^{\circ} \mathrm{C}, 30 \%$ of maximal power, $10 \mathrm{~min}$ on $200{ }^{\circ} \mathrm{C}, 30 \%$ of power, $30 \mathrm{~min}$ on $30{ }^{\circ} \mathrm{C}, 0 \%$ of power. The mineralised samples were filled up to the final volume of $10 \mathrm{ml}$ with deionised water (conductivity 0.055 $\mu \mathrm{S} / \mathrm{cm}$, Evoqua Water Technologies, Germany).

The elemental analysis of $\mathrm{Ca}, \mathrm{Co}, \mathrm{Cr}, \mathrm{Mg}$, and $\mathrm{Ni}$ was carried out using the sequential, radially viewed ICP OES spectrometer INTEGRA 6000 (GBC, Dandenong Australia) equipped with the ultrasonic nebulizer U5000AT+ (Teledyne Cetac Technologies, the USA), concentric nebulizer $\left(2 \mathrm{ml} . \mathrm{min}^{-1}\right)$ and a glass cyclonic spray chamber (both Glass Expansion, Australia). The analytical lines used were Mg 285.2213 nm, Ca 422.673 nm, Ni 221.647 nm, Co 238.892 $\mathrm{nm}$, and Cr $267.716 \mathrm{~nm}$. The operation conditions of the ICP OES analysis were as follows: sample flow rate $1.5 \mathrm{~mL} \cdot \mathrm{min}^{-1}$, plasma power $1000 \mathrm{~W}$, plasma, auxiliary and nebulizer gas flow rates 10, 0.4, and $0.52 \mathrm{~L} \cdot \mathrm{min}^{-1}$, respectively, photomultiplier voltage $600 \mathrm{~V}$ for $\mathrm{Co}, \mathrm{Cr}$, and $\mathrm{Ni}$ and $350 \mathrm{~V}$ for $\mathrm{Ca}$ and $\mathrm{Mg}$, view height $6.5 \mathrm{~mm}$, three replicated reading on-peak $1 \mathrm{~s}$, fixed point background correction. The multielement standards containing $10-5-1-0.5-$ $0.1 \mathrm{mg} . \mathrm{L}^{-1}$ of $\mathrm{Mg}$ and $\mathrm{Ca}$ and $0.1-0.05-0.01-0.005-0.001 \mathrm{mg} . \mathrm{L}^{-1}$ of $\mathrm{Co}, \mathrm{Cr}$, and $\mathrm{Ni}$ were used for instrument calibration. The external calibration standards were prepared using standard solutions of $\mathrm{Ca}, \mathrm{Co}, \mathrm{Cr}, \mathrm{Mg}$, and $\mathrm{Ni}$ all containing 1 g. $\mathrm{L}^{-1}$ (SCP, Canada). The limits of detection (concentration equal to three times the standard deviation at the point of the background correction) were $0.0005 \mu \mathrm{g} . \mathrm{L}^{-1}$ for $\mathrm{Co}, \mathrm{Cr}$, and $\mathrm{Ni}$ and $2 \mu \mathrm{g} . \mathrm{L}^{-1}$ for $\mathrm{Ca}$ and $\mathrm{Mg}$. Certified reference material (Bush twigs and leaves GBW 07602 from the China National Analysis Centre for Iron and Steel, Beijing) was used to validate the method and for the quality control.

For the elemental soil analysis, we used extraction method of Mehlich III (Zbíral et al., 2016). The extraction buffer contained: $0.2 \mathrm{~mol} / \mathrm{L} \mathrm{CH}_{3} \mathrm{COOH}, 0.015 \mathrm{~mol} / \mathrm{L} \mathrm{NH}_{4} \mathrm{~F}, 0.013 \mathrm{~mol} / \mathrm{L}$ 
bioRxiv preprint doi: https://doi.org/10.1101/2022.02.26.482078; this version posted February 26, 2022. The copyright holder for this preprint (which was not certified by peer review) is the author/funder. All rights reserved. No reuse allowed without permission.

$\mathrm{HNO}_{3}, 0.25 \mathrm{~mol} / \mathrm{L} \mathrm{NH}_{4} \mathrm{NO}_{3}, 0.001 \mathrm{~mol} / \mathrm{L}$ EDTA. We mixed $100 \pm 0,5 \mathrm{~mL}$ of extraction buffer with $10 \mathrm{~g}$ of fine-grained soil $(2 \mathrm{~mm})$ and spiked them for $10 \mathrm{~min}$.

\section{Root growth experiments in calcium/magnesium solutions}

The control medium $(\mathrm{Ca} / \mathrm{Mg}$ ratio 1.97) was based on one-fifth strength Murashige-Skoog medium and contained: $3.76 \mathrm{mM} \mathrm{KNO}_{3}, 0.25 \mathrm{mM} \mathrm{KH}_{2} \mathrm{PO}_{4}, 0.3 \mathrm{mM} \mathrm{MgSO}_{4}, 0.59 \mathrm{mM} \mathrm{CaCl}_{2}$, $20 \mu \mathrm{M} \mathrm{H}_{3} \mathrm{BO}_{3}, 0.02 \mu \mathrm{M} \mathrm{CoCl}_{2}, 0.02 \mu \mathrm{M} \mathrm{CuSO}_{4}, 20 \mu \mathrm{M} \mathrm{FeSO}_{4}, 22.4 \mu \mathrm{M} \mathrm{MnSO}_{4}, 0.21 \mu \mathrm{M}$ $\mathrm{Na}_{2} \mathrm{MoO}_{4}, 1 \mu \mathrm{M} \mathrm{KI}$, and $5.98 \mu \mathrm{M} \mathrm{ZnSO}_{4}$. Medium with $\mathrm{Ca} / \mathrm{Mg}$ ratio 0.04 contained $0.2 \mathrm{mM}$ $\mathrm{CaCl}_{2}$ and $4.5 \mathrm{mM}$ of $\mathrm{MgCl}_{2}$ according to Bradshaw (2005). Medium with $\mathrm{Ca} / \mathrm{Mg}$ ratio 0.2 contained $2.15 \mathrm{mM} \mathrm{CaCl} 2$ and $6.97 \mathrm{mM} \mathrm{MgCl}_{2}$. Other salts were added in the same concentrations as in the control medium. All media were supplemented with $1 \% \mathrm{w} / \mathrm{v}$ sucrose and solidified with $1 \%$ w/v agar (Plant agar; Duchefa, Netherlands). $\mathrm{pH}$ of the media was adjusted to 6.0 by $\mathrm{NaOH}$.

Seeds were surface sterilized with $20 \%$ solution of commercial bleach with $0.1 \%$ triton for $15 \mathrm{~min}$ and washed with distilled water three times. Sterilized seeds were sown on a control medium in the $120 \times 120 \mathrm{~mm}$ sterile plates and vernalised at $4{ }^{\circ} \mathrm{C}$ and in the dark for 7 days. After vernalisation, seeds were germinated in a cultivation room with constant growth conditions $\left(22 / 18{ }^{\circ} \mathrm{C}\right.$ day/night temperature, 16/8 hours light/dark cycle). Six days after germination seedlings were transferred onto media with $\mathrm{Ca} / \mathrm{Mg}$ ratios 0.2 and 0.04 and cultivated for the next nine days in the same cultivation conditions. We fixed plants on the 15 th day after germination in $4 \%$ formaldehyde overnight, degassed under vacuum, and gradually saturated with $15 \%$ and $30 \%$ glycerol. Roots of glycerol-saturated plants were scanned at high resolution (1200dpi, 24-bit) and root system traits were measured by Root analyser plug-in in NIS Elements AR 3.22.05 software (Laboratory Imaging). 


\section{SUPPLEMENTARY TABLES AND FIGURES}

STable 1. Details on sampled populations.

\begin{tabular}{|c|c|c|c|c|c|c|c|c|c|}
\hline \multirow[t]{2}{*}{ Pop } & \multirow[t]{2}{*}{ Ploidy } & \multirow[t]{2}{*}{$\begin{array}{l}\text { Population } \\
\text { name }\end{array}$} & $\begin{array}{l}\text { Natural } \\
\text { populations }\end{array}$ & Experiment & \multirow[t]{2}{*}{$\begin{array}{l}\text { Bedrock } \\
\text { type }\end{array}$} & \multirow[t]{2}{*}{ Altitude } & \multirow[t]{2}{*}{ Latitude } & \multirow[t]{2}{*}{ Longitude } & \multirow[t]{2}{*}{ Country } \\
\hline & & & $\begin{array}{l}\mathrm{N} \text { ind } \\
\text { genome/soil } \\
\text { ionomics }\end{array}$ & $\begin{array}{l}\mathrm{N} \text { ind } \\
\text { cultivated in } \\
\text { total/ionomics } \\
\mathrm{S} \text { treatment }\end{array}$ & & & & & \\
\hline $\mathrm{S} 1$ & $4 x$ & Borovsko & $7 / 8$ & $47 / 10$ & serpentine & 416 & 49.68381 & 15.13326 & $\mathrm{CZ}$ \\
\hline $\mathrm{S} 2$ & $4 \mathrm{x}$ & Steinegg & $7 / 8$ & $50 / 10$ & serpentine & 414 & 48.62993 & 15.54256 & $\mathrm{AT}$ \\
\hline $\mathrm{S} 3$ & $4 \mathrm{x}$ & Gulsen & $8 / 8$ & $45 / 10$ & serpentine & 628 & 47.28167 & 14.92764 & $\mathrm{AT}$ \\
\hline $\mathrm{N} 1$ & $4 \mathrm{x}$ & Vlastejovice & $8 / 8$ & $48 / 7$ & siliceous & 345 & 49.73496 & 15.17484 & $\mathrm{CZ}$ \\
\hline $\mathrm{N} 2$ & $4 \mathrm{x}$ & Fuglau & $8 / 8$ & $50 / 9$ & siliceous & 436 & 48.63149 & 15.55723 & $\mathrm{AT}$ \\
\hline N3 & $4 x$ & Ingeringgraben & $8 / 8$ & $44 / 10$ & siliceous & 950 & 47.28405 & 14.68154 & $\mathrm{AT}$ \\
\hline
\end{tabular}

STable 2. Overview of survival and transition to reproduction of individuals in reciprocal transplant experiment.

\begin{tabular}{|l|l|l|l|l|l|}
\hline Pop & Treatment & $\begin{array}{l}\text { Total N } \\
\text { of plants }\end{array}$ & Buds & Flowers & Fruits \\
\hline N1 & S & 24 & 21 & 13 & 6 \\
\hline N1 & N & 24 & 24 & 22 & 20 \\
\hline N2 & S & 25 & 24 & 8 & 3 \\
\hline N2 & N & 25 & 24 & 19 & 14 \\
\hline N3 & S & 22 & 18 & 13 & 8 \\
\hline N3 & N & 22 & 19 & 17 & 15 \\
\hline S1 & S & 23 & 23 & 21 & 17 \\
\hline S1 & N & 24 & 23 & 22 & 21 \\
\hline S2 & S & 25 & 23 & 9 & 4 \\
\hline S2 & N & 25 & 25 & 22 & 15 \\
\hline S3 & S & 23 & 22 & 22 & 22 \\
\hline S3 & N & 22 & 22 & 19 & 17 \\
\hline
\end{tabular}


STable 3. The effects of substrate of origin, population pair and their interaction on total fitness inferred by an aster hierarchical model. The aster models consisted of four fitness components, which were aligned in the following directional graph: proportion to bolting $\rightarrow$ proportion to flowering $\rightarrow$ fruit production $\rightarrow$ total seed mass production. All factors were tested by likelihood ratio tests using nested null models (model separately with substrate of origin or treatment effects were compared to model including both factors, further the model with both substrate of origin and population pair effects were compared to mode with substrate of origin*population pair interaction).

\begin{tabular}{|l|l|l|l|l|l|l|l|l|}
\hline Treatment & $\begin{array}{l}\text { Tested } \\
\text { factor }\end{array}$ & $\begin{array}{l}\text { Null } \\
\text { df }\end{array}$ & $\begin{array}{l}\text { Alternative } \\
\text { df }\end{array}$ & $\begin{array}{l}\text { Null } \\
\text { deviance }\end{array}$ & $\begin{array}{l}\text { Alternative } \\
\text { deviance }\end{array}$ & $\begin{array}{l}\text { Test } \\
\text { df }\end{array}$ & $\begin{array}{l}\text { Test } \\
\text { deviance }\end{array}$ & $p$ value \\
\hline serpentine & $\begin{array}{l}\text { Substrate } \\
\text { of origin }\end{array}$ & 5 & 7 & 20002 & 20346 & 2 & -344 & $<0.0001$ \\
\hline & $\begin{array}{l}\text { Population } \\
\text { pair }\end{array}$ & 6 & 7 & 20031 & 20346 & 1 & -315 & $<0.0001$ \\
\hline & $\begin{array}{l}\text { Substrate } \\
\text { of origin + } \\
\text { Population } \\
\text { pair }\end{array}$ & 7 & 9 & 20346 & 20384 & 2 & -38 & $<0.0001$ \\
\hline $\begin{array}{l}\text { Substrate } \\
\text { of origin }\end{array}$ & 5 & 7 & 28718 & 29566 & 2 & -848 & $<0.0001$ \\
\hline & $\begin{array}{l}\text { Population } \\
\text { pair }\end{array}$ & 6 & 7 & 29554 & 29566 & 1 & -12 & 0.0005 \\
\hline & $\begin{array}{l}\text { Substrate } \\
\text { of origin }+ \\
\text { Population } \\
\text { pair }\end{array}$ & 7 & 9 & 29566 & 29647 & 2 & -81 & $<0.0001$ \\
\hline
\end{tabular}

STable 4. Differences in total fitness inferred by hierarchical aster models separately for each population pair in serpentine and non-serpentine treatment. The differences were tested using likelihood ratio tests.

\begin{tabular}{|l|l|l|l|l|}
\hline \multirow{2}{*}{ Population pair } & \multicolumn{2}{|l|}{ Serpentine treatment } & \multicolumn{2}{l|}{ Non-serpentine treatment } \\
\cline { 2 - 5 } & $\chi^{2}$ & $p$ value & $\chi 2$ & $p$ value \\
\hline S1-N1 & 19.52 & $<0.0001$ & 0.0006 & 0.9798 \\
\hline S2-N2 & 0.45 & 0.5002 & 1.14 & 0.2851 \\
\hline S3-N3 & 366.48 & $<0.0001$ & 2.35 & 0.1251 \\
\hline
\end{tabular}


STable 5 Contribution of phenotypic traits to cumulative fitness of $A$. arenosa serpentine and non-serpentine plants.

\begin{tabular}{|c|c|c|c|c|c|c|c|c|}
\hline Pop & Treatment & $\begin{array}{l}\mathrm{N} \text { indiv total/total } \\
\text { seed mass } \\
\text { production/above- } \\
\text { ground biomass }\end{array}$ & $\begin{array}{l}\text { Flower } \\
\text { production } \\
\text { and early } \\
\text { survival }\end{array}$ & $\begin{array}{l}\text { Fruit } \\
\text { production }\end{array}$ & \begin{tabular}{|l} 
Late \\
survival
\end{tabular} & $\begin{array}{l}\text { Total seed } \\
\text { mass } \\
\text { production }\end{array}$ & $\begin{array}{l}\text { Above- } \\
\text { ground } \\
\text { biomass }\end{array}$ & $\begin{array}{l}\text { Cumulative } \\
\text { fitness }\end{array}$ \\
\hline N1 & S & $24 / 6 / 10$ & 0.541667 & 0.461538 & 0.833333 & 0.02911 & 0.018178 & 0.00011 \\
\hline $\mathrm{N} 2$ & S & $25 / 3 / 16$ & 0.32 & 0.375 & 1 & 0.103093 & 0.259713 & 0.003213 \\
\hline N3 & S & $22 / 8 / 18$ & 0.590909 & 0.615385 & 1 & 1.989026 & 1.115717 & 0.806978 \\
\hline S1 & S & $23 / 17 / 17$ & 0.913043 & 0.809524 & 0.823529 & 0.777088 & 0.191078 & 0.090382 \\
\hline $\mathrm{S} 2$ & S & $25 / 4 / 13$ & 0.36 & 0.444444 & 0.5 & 0.3585 & 0.35725 & 0.010246 \\
\hline S3 & S & $23 / 22 / 22$ & 0.956522 & 1 & 0.954545 & 2.818786 & 0.927159 & 2.386207 \\
\hline N1 & $\mathrm{N}$ & $24 / 20 / 16$ & 0.916667 & 0.909091 & 0.7 & 0.857097 & 1.143467 & 0.571703 \\
\hline $\mathrm{N} 2$ & $\mathrm{~N}$ & $25 / 14 / 12$ & 0.76 & 0.736842 & 0.857143 & 1.21923 & 0.955973 & 0.559464 \\
\hline N3 & $\mathrm{N}$ & $22 / 15 / 14$ & 0.772727 & 0.882353 & 0.8 & 0.893986 & 1.02013 & 0.497445 \\
\hline S1 & $\mathrm{N}$ & $24 / 21 / 11$ & 0.916667 & 0.954545 & 0.47619 & 1.136098 & 0.791321 & 0.374591 \\
\hline S2 & $\mathrm{N}$ & $25 / 15 / 21$ & 0.88 & 0.681818 & 0.933333 & 0.795385 & 1.044027 & 0.465026 \\
\hline S3 & $\mathrm{N}$ & $22 / 17 / 17$ & 0.863636 & 0.894737 & 0.882353 & 1.093541 & 0.983422 & 0.733236 \\
\hline
\end{tabular}


STable 6. Summary of linear models (LM) testing the effect of substrate of origin, the effect of population pair and their interactions on functional traits (ion uptake, morphological life-history traits, and fitness proxies) of plants cultivated in serpentine soils. Tests of significance for individual fixed effect factors and interaction were conducted by Type III Wald $\chi^{2}$ tests.

\begin{tabular}{|c|c|c|c|c|c|c|c|c|c|c|}
\hline \multirow[t]{2}{*}{$\begin{array}{l}\text { Response } \\
\text { variable }\end{array}$} & \multirow[t]{2}{*}{ Transformation } & \multicolumn{3}{|c|}{ Substrate of origin } & \multicolumn{3}{|c|}{ Pop. pair } & \multicolumn{3}{|c|}{$\begin{array}{l}\text { Substrate } \\
\text { origin*pop.pair }\end{array}$} \\
\hline & & Df & $x^{2}$ & $p$ & $\mathrm{Df}$ & $x^{2}$ & $p$ & Df & $x^{2}$ & $p$ \\
\hline $\mathrm{Ca}[\mathrm{ppm}]$ & $\log$ & 1 & 18.1277 & $* * *$ & 2 & 9.3029 & $* * *$ & 2 & 2.6932 & . \\
\hline $\mathrm{Mg}[\mathrm{ppm}]$ & $\log$ & 1 & 5.4663 & $*$ & 2 & 7.3841 & $* *$ & 2 & 2.6947 & . \\
\hline $\mathrm{Ca} / \mathrm{Mg}$ & $\log$ & 1 & 5.569 & $*$ & 2 & 7.8672 & $* *$ & 2 & 15.0728 & $* * *$ \\
\hline Co [ppm] & $\log$ & 1 & 10.5126 & $* *$ & 2 & 10.7253 & $* * *$ & 2 & 1.1056 & $\mathrm{~ns}$ \\
\hline $\mathrm{Cr}[\mathrm{ppm}]$ & $\log$ & 1 & 22.911 & $* * *$ & 2 & 41.466 & $* * *$ & 2 & 11.793 & $* * *$ \\
\hline $\mathrm{Ni}$ [ppm] & $\log$ & 1 & 14.3601 & $* * *$ & 2 & 62.4837 & $* * *$ & 2 & 4.8947 & $*$ \\
\hline $\begin{array}{l}\text { Bolting } \quad \text { time } \\
\text { [days] }\end{array}$ & $\log$ & 1 & 2.0948 & ns & 2 & 26.8956 & $* * *$ & 2 & 12.4542 & $* * *$ \\
\hline $\begin{array}{l}\text { Flowering time } \\
\text { [days] }\end{array}$ & $\log$ & 1 & 0.007 & ns & 2 & 2.8453 & . & 2 & 5.116 & $* *$ \\
\hline $\begin{array}{l}\text { Rosette } \\
{\left[\mathrm{mm}^{2}\right]}\end{array} \quad$ area & sqrt & 1 & 122.226 & $* * *$ & 2 & 6.6118 & $* *$ & 2 & 9.7281 & $* * *$ \\
\hline $\begin{array}{l}\mathrm{N} \text { of additive } \\
\text { rosettes }\end{array}$ & $\log$ & 1 & 38.815 & $* * *$ & 2 & 11.1697 & $* * *$ & 2 & 4.7695 & $*$ \\
\hline $\begin{array}{l}\text { Total seed mass } \\
\text { production }[\mathrm{mg}]\end{array}$ & $\log$ & 1 & 31.0958 & $* * *$ & 2 & 7.204 & $* *$ & 2 & 3.3422 & $*$ \\
\hline $\begin{array}{l}\text { Above-ground } \\
\text { biomass [mg] }\end{array}$ & sqrt & 1 & 12.2657 & $* * *$ & 2 & 12.3582 & $* * *$ & 2 & 4.7489 & $*$ \\
\hline $\begin{array}{l}\text { Root biomass } \\
{[\mathrm{mg}]}\end{array}$ & $\log$ & 1 & 13.5719 & $* *$ & 2 & 14.7037 & $* * *$ & 2 & 3.3024 & . \\
\hline
\end{tabular}


STable 7. Effects of substrate of origin (S vs. N), treatment (S vs. N), and their interactions on functional traits tested by linear models (LM), binomial generalized linear models (GLM binomial), and linear mixed effect models (LMM) for each population pair separately. Tests of significance for individual fixed effect factors and interaction were conducted by Type III Wald $\chi 2$ tests. The random effects in LMM were cultivation run and Petri dish for cultivation.

\begin{tabular}{|c|c|c|c|c|c|c|c|c|c|c|c|c|}
\hline \multirow{2}{*}{$\begin{array}{l}\text { Response } \\
\text { variable }\end{array}$} & \multirow{2}{*}{$\begin{array}{c}\text { Tran } \\
\text { sfor } \\
\text { mati } \\
\text { on }\end{array}$} & \multirow[t]{2}{*}{ Model } & \multirow{2}{*}{$\begin{array}{l}\text { Pop. } \\
\text { pair }\end{array}$} & \multicolumn{3}{|c|}{ Substrate of origin } & \multicolumn{3}{|c|}{ Treatment } & \multicolumn{3}{|c|}{ Ecotype*treatment } \\
\hline & & & & $\mathrm{df}$ & $\chi^{2}$ & $p$ & $\mathrm{df}$ & $\chi^{2}$ & $p$ & $\mathrm{df}$ & $\chi^{2}$ & $p$ \\
\hline $\begin{array}{l}\text { Bolting } \\
\text { time } \\
\text { [days] }\end{array}$ & $\log$ & LM & 1 & 1 & 1.6173 & ns & 1 & 5.3656 & $*$ & 1 & 1.9493 & ns \\
\hline $\begin{array}{l}\text { Bolting } \\
\text { time } \\
\text { [days] }\end{array}$ & $\log$ & LM & 2 & 1 & 5.4496 & $*$ & 1 & 9.5134 & $* *$ & 1 & 0.1474 & $\mathrm{~ns}$ \\
\hline $\begin{array}{l}\text { Bolting } \\
\text { time } \\
\text { [days] }\end{array}$ & $\log$ & $\mathrm{LM}$ & 3 & 1 & 60.53 & $* * *$ & 1 & 10.794 & $* *$ & 1 & $\begin{array}{l}12.192 \\
9\end{array}$ & $* * *$ \\
\hline $\begin{array}{l}\text { Flowering } \\
\text { time } \\
\text { [days] }\end{array}$ & $\log$ & LM & 1 & 1 & 0.0067 & ns & 1 & 4.1831 & $*$ & 1 & 0.0465 & ns \\
\hline $\begin{array}{l}\text { Flowering } \\
\text { time } \\
\text { [days] }\end{array}$ & $\log$ & LM & 2 & 1 & 2.1932 & ns & 1 & 2.1896 & $\mathrm{~ns}$ & 1 & 6.3390 & $*$ \\
\hline $\begin{array}{l}\text { Flowering } \\
\text { time } \\
\text { [days] }\end{array}$ & $\log$ & LM & 3 & 1 & 17.732 & $* * *$ & 1 & $\begin{array}{l}5.1573 \\
7\end{array}$ & $* *$ & 1 & 5.1469 & $*$ \\
\hline $\begin{array}{l}\text { Rosette } \\
\text { area } \\
{\left[\mathrm{mm}^{2}\right]}\end{array}$ & sqrt & LM & 1 & 1 & 48.676 & $* * *$ & 1 & $\begin{array}{l}251.72 \\
2\end{array}$ & $* * *$ & 1 & 33.82 & $* * *$ \\
\hline $\begin{array}{l}\text { Rosette } \\
\text { area } \\
{\left[\mathrm{mm}^{2}\right]}\end{array}$ & sqrt & LM & 2 & 1 & $\begin{array}{l}42.691 \\
2\end{array}$ & $* * *$ & 1 & $\begin{array}{l}144.23 \\
52\end{array}$ & $* * *$ & 1 & 7.9263 & $* *$ \\
\hline $\begin{array}{l}\text { Rosette } \\
\text { area } \\
{\left[\mathrm{mm}^{2}\right]}\end{array}$ & sqrt & LM & 3 & 1 & 85.345 & $* * *$ & 1 & $\begin{array}{l}53.616 \\
1\end{array}$ & $* * *$ & 1 & 35.877 & $* * *$ \\
\hline $\begin{array}{l}\mathrm{N} \text { of } \\
\text { additive } \\
\text { rosettes }\end{array}$ & $\log$ & LM & 1 & 1 & $\begin{array}{l}25.152 \\
1\end{array}$ & $* * *$ & 1 & $\begin{array}{l}66.807 \\
9\end{array}$ & $* * *$ & 1 & $\begin{array}{l}10.401 \\
1\end{array}$ & $* *$ \\
\hline $\begin{array}{l}\mathrm{N} \text { of } \\
\text { additive } \\
\text { rosettes }\end{array}$ & $\log$ & LM & 2 & 1 & $\begin{array}{l}13.212 \\
3\end{array}$ & $* * *$ & 1 & $\begin{array}{l}94.488 \\
2\end{array}$ & $* * *$ & 1 & 2.2259 & $\mathrm{~ns}$ \\
\hline
\end{tabular}




\begin{tabular}{|c|c|c|c|c|c|c|c|c|c|c|c|c|}
\hline $\begin{array}{l}\mathrm{N} \text { of } \\
\text { additive } \\
\text { rosettes }\end{array}$ & $\log$ & $\mathrm{LM}$ & 3 & 1 & 6.4998 & $*$ & 1 & 3.4469 & $*$ & 1 & 4.1851 & $*$ \\
\hline $\begin{array}{l}\text { Probabilit } \\
y \text { of fruit } \\
\text { production } \\
(0 / 1)\end{array}$ & & $\begin{array}{l}\text { GLM } \\
\text { binomial }\end{array}$ & 1 & 1 & $\begin{array}{l}10.229 \\
5\end{array}$ & $* *$ & 1 & 14.043 & $* * *$ & 1 & 2.8821 & . \\
\hline $\begin{array}{l}\text { Probabilit } \\
y \text { of fruit } \\
\text { production } \\
(0 / 1)\end{array}$ & & $\begin{array}{l}\text { GLM } \\
\text { binomial }\end{array}$ & 2 & 1 & 0.1651 & $\mathrm{~ns}$ & 1 & 9.2197 & $* *$ & 1 & 0.0287 & ns \\
\hline $\begin{array}{l}\text { Probabilit } \\
\mathrm{y} \text { of fruit } \\
\text { production } \\
(0 / 1)\end{array}$ & & $\begin{array}{l}\text { GLM } \\
\text { binomial }\end{array}$ & 3 & 1 & $\begin{array}{l}10.734 \\
2\end{array}$ & $* *$ & 1 & 4.3036 & $*$ & 1 & 5.9476 & $*$ \\
\hline $\begin{array}{l}\text { Total seed } \\
\text { mass } \\
\text { production } \\
{[\mathrm{mg}]}\end{array}$ & $\log$ & LM & 1 & 1 & $\begin{array}{l}27.762 \\
9\end{array}$ & $* * *$ & 1 & $\begin{array}{l}27.446 \\
6\end{array}$ & $* * *$ & 1 & 12.937 & $* * *$ \\
\hline $\begin{array}{l}\text { Total seed } \\
\text { mass } \\
\text { production } \\
{[\mathrm{mg}]}\end{array}$ & $\log$ & LM & 2 & 1 & 1.5909 & $\mathrm{~ns}$ & 1 & 7.0795 & $*$ & 1 & 4.2835 & $*$ \\
\hline $\begin{array}{l}\text { Total seed } \\
\text { mass } \\
\text { production } \\
{[\mathrm{mg}]}\end{array}$ & $\log$ & LM & 3 & 1 & 6.4173 & $*$ & 1 & 0.0225 & $\mathrm{~ns}$ & 1 & 3.0056 & \\
\hline $\begin{array}{l}\text { Above- } \\
\text { ground } \\
\text { biomass } \\
{[\mathrm{mg}]}\end{array}$ & sqrt & $\mathrm{LM}$ & 2 & 1 & 1.8036 & . & 1 & $\begin{array}{l}39.142 \\
7\end{array}$ & $* * *$ & 1 & 0.3055 & ns \\
\hline $\begin{array}{l}\text { Above- } \\
\text { ground } \\
\text { biomass } \\
{[\mathrm{mg}]}\end{array}$ & sqrt & $\mathrm{LM}$ & 3 & 1 & 0.3318 & $\mathrm{~ns}$ & 1 & 0.0068 & $\mathrm{~ns}$ & 1 & 0.0252 & ns \\
\hline $\begin{array}{l}\text { Root } \\
\text { biomass } \\
{[\mathrm{mg}]}\end{array}$ & $\log$ & $\mathrm{LM}$ & 1 & 1 & 19.738 & $* * *$ & 1 & 77.331 & $* * *$ & 1 & 17.991 & $* * *$ \\
\hline $\begin{array}{l}\text { Root } \\
\text { biomass } \\
{[\mathrm{mg}]}\end{array}$ & $\log$ & LM & 2 & 1 & 5.6086 & $*$ & 1 & $\begin{array}{l}25.390 \\
2\end{array}$ & $* * *$ & 1 & 4.8871 & $*$ \\
\hline $\begin{array}{l}\text { Root } \\
\text { biomass } \\
{[\mathrm{mg}]}\end{array}$ & $\log$ & $\mathrm{LM}$ & 3 & 1 & 0.0142 & $\mathrm{~ns}$ & 1 & 0.5516 & $\mathrm{~ns}$ & 1 & 5.0671 & $*$ \\
\hline
\end{tabular}




\begin{tabular}{|c|c|c|c|c|c|c|c|c|c|c|c|c|}
\hline $\begin{array}{l}\text { Probabilit } \\
\mathrm{y} \text { of late } \\
\text { survival } \\
\text { (after fruit } \\
\text { production } \\
\text { ) }(0 / 1)\end{array}$ & & $\begin{array}{l}\text { GLM } \\
\text { binomial }\end{array}$ & 1 & 1 & 6.5438 & $*$ & 1 & 8.0743 & $* *$ & 1 & 2.1933 & ns \\
\hline $\begin{array}{l}\text { Probabilit } \\
y \text { of late } \\
\text { survival } \\
\text { (after fruit } \\
\text { production } \\
\text { (0/1) }\end{array}$ & & $\begin{array}{l}\text { GLM } \\
\text { binomial }\end{array}$ & 3 & 1 & 0.0001 & . & 1 & 0.1392 & ns & 1 & 0.0001 & . \\
\hline $\begin{array}{l}\text { Total root } \\
\text { growth } \\
{[\mathrm{cm}]}\end{array}$ & $\log$ & LMM & 1 & 1 & 126.12 & $* * *$ & 2 & 61.19 & $* * *$ & 2 & 45.36 & $* * *$ \\
\hline $\begin{array}{l}\text { Total root } \\
\text { growth } \\
{[\mathrm{cm}]}\end{array}$ & $\log$ & LMM & 2 & 1 & 72.507 & $* * *$ & 2 & $\begin{array}{l}102.22 \\
5\end{array}$ & $* * *$ & 2 & 44.424 & $* * *$ \\
\hline $\begin{array}{l}\text { Total root } \\
\text { growth } \\
{[\mathrm{cm}]}\end{array}$ & $\log$ & LMM & 3 & 1 & $\begin{array}{l}119.72 \\
9\end{array}$ & $* * *$ & 2 & 79.918 & $* * *$ & 2 & 26.266 & $* * *$ \\
\hline $\begin{array}{l}\text { Main root } \\
\text { length } \\
{[\mathrm{cm}]}\end{array}$ & & LMM & 3 & 1 & 92.897 & $* * *$ & 2 & 54.702 & $* * *$ & 2 & 23.9 & $* * *$ \\
\hline $\begin{array}{l}\text { Density of } \\
\text { lateral roots } \\
\text { (number of } \\
\text { lateral } \\
\text { roots/main } \\
\text { root length) }\end{array}$ & sqrt & LMM & 1 & 1 & 16.617 & $* * *$ & 2 & 26.164 & $* * *$ & 2 & 10.292 & $* *$ \\
\hline $\begin{array}{l}\text { Density of } \\
\text { lateral roots } \\
\text { (number of } \\
\text { lateral } \\
\text { roots/main } \\
\text { root length) }\end{array}$ & sqrt & LMM & 2 & 1 & 22.098 & $* * *$ & 2 & 20.394 & $* * *$ & 2 & 10.882 & $* *$ \\
\hline
\end{tabular}




\begin{tabular}{|l|l|l|l|l|l|l|l|l|l|l|l|}
\hline $\begin{array}{l}\text { Density of } \\
\text { lateral roots } \\
\text { (number of }\end{array}$ & sqrt & LMM & 3 & 1 & 156.26 & $* * *$ & 2 & 108.78 & $* * *$ & 2 & 54.395 \\
$\begin{array}{l}\text { lateral } \\
\text { roots/main } \\
\text { root length) }\end{array}$ & & & & & & & & & & & \\
\hline
\end{tabular}

${ }^{* * *} p<0.001{ }^{* *} p<0.01 ;^{*} p<0.05 ; \cdot p<0.1$

STable 8. Quantification of parallelism by genes and functions. Percentages of shared differentiation candidate genes and significantly enriched gene ontology terms $(p<0.05)$ in biological processes domain - BP, molecular functions - MF, and cellular components - CC between any two population pairs when applying the classic algorithm (Alexa and Rahnenfuhrer, 2020). We calculated proportion of shared genes or functions as number of shared differentiation candidate genes or gene ontology (GO) terms per each two population pairs divided by the total number of differentiation candidate genes or GO terms for selected population pair combination. Percentages of shared enriched gene ontology terms, which were calculated based on GO enrichment without parallel differentiation candidates, are given in brackets.

\begin{tabular}{|l|l|l|l|}
\hline Level & S1-N1 - S2-N2 & S1-N1 - S3-N3 & S2-N2 - S3-N3 \\
\hline genes & $2.38 \%$ & $2.40 \%$ & $2.16 \%$ \\
\hline enriched gene ontology terms BP & $8.43 \%(5.06 \%)$ & $3.87 \%(4.43 \%)$ & $2.02 \%(1.17 \%)$ \\
\hline enriched gene ontology terms MF & $6.52 \%(1.54 \%)$ & $5.43 \%(1.6 \%)$ & $8.06 \%(1.7 \%)$ \\
\hline enriched gene ontology terms CC & $8.41 \%(7.02 \%)$ & $5.56 \%(5.77 \%)$ & $5.49 \%(2.17 \%)$ \\
\hline
\end{tabular}

STable 9. Number of protein interactions inferred by STRING for candidate differentiation genes for each population pair.

\begin{tabular}{|l|l|l|l|r|r|}
\hline $\begin{array}{l}\text { Population } \\
\text { pair }\end{array}$ & $\begin{array}{l}\text { N } \\
\text { differentiation } \\
\text { candidate } \\
\text { genes }\end{array}$ & $\begin{array}{l}\text { N differentiation } \\
\text { candidate genes } \\
\text { interacted in } \\
\text { total }\end{array}$ & $\begin{array}{l}\text { N differentiation } \\
\text { candidate genes } \\
\text { interacted with } \\
\text { genes from at least } \\
\text { one other } \\
\text { population pair }\end{array}$ & Proportion $^{1}$ & Proportion $^{2}$ \\
\hline S1-N1 & 494 & 358 & 340 & 0.72 & 0.69 \\
\hline S2-N2 & 513 & 357 & 332 & 0.7 & 0.65 \\
\hline S3-N3 & 504 & 363 & 333 & 0.72 & 0.66 \\
\hline
\end{tabular}


A

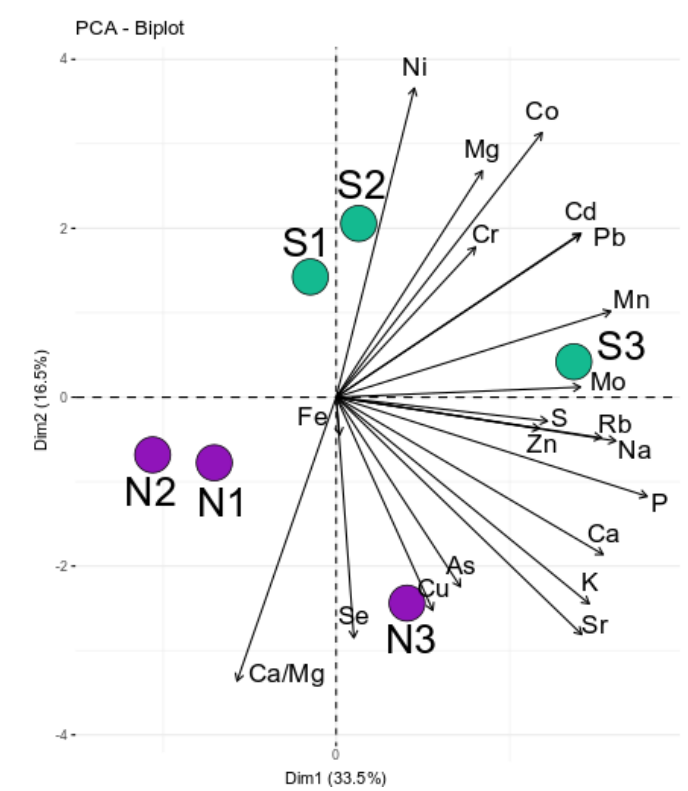

B

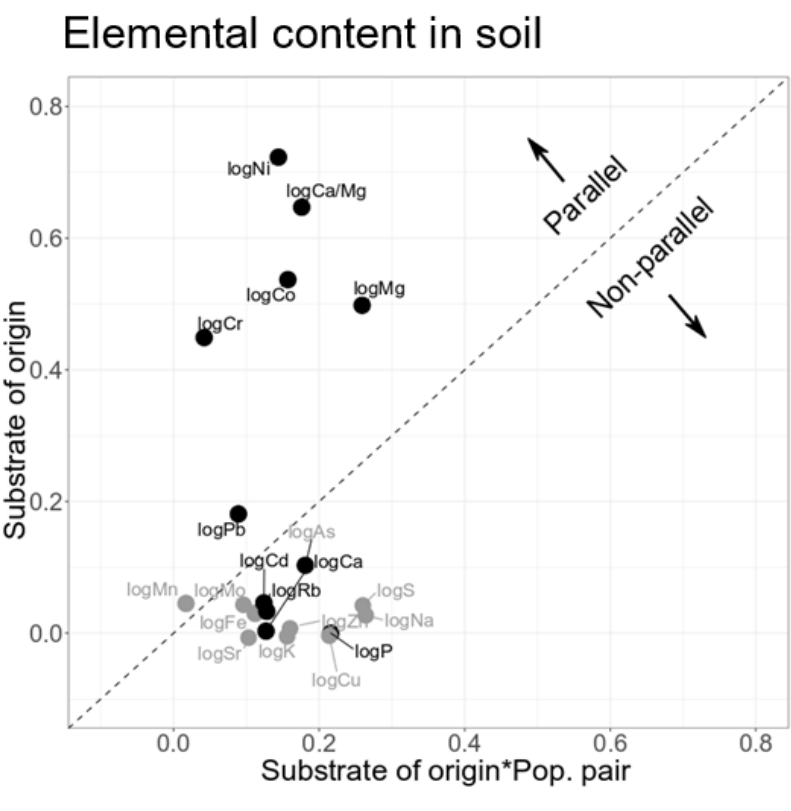

SFig. 1. A) PCA based on all soil variables (population means of 7/8 individual observations STable 1) measured at original sites showing the differentiation between $\mathrm{S}$ and $\mathrm{N}$ soils. Serpentine ( $\mathrm{S}$, green dots) and non-serpentine (N, violet dots). B) Variation in the extent of parallelism among individual soil elemental concentrations from natural populations. The extent of parallelism was estimated as effect sizes (Eta2) in linear models addressing the effect of substrate of origin ( $\mathrm{S}$ vs. N), pop. pair $(1,2,3)$ and their interaction, calculated separately for each trait (particular elemental soil concentration and $\mathrm{Ca} / \mathrm{Mg}$ ratio). The effect size of substrate of origin (y-axis) shows the extent to which a given trait diverges predictably between substrate of origins, i.e., in parallel, while the substrate of origin*pop. pair effect size (x axis) quantifies the extent to which serpentine/non-serpentine soil divergence varies across population pairs (i.e., deviates from parallel). Points falling above the dashed line have a larger substrate of origin effect (i.e. parallel) than substrate of origin*pop. pair interaction effect (i.e. nonparallel). Note: green arrows indicate the trend in all serpentine populations; grey points indicate the non-significant $(p<0.05)$ effect of substrate of origin.

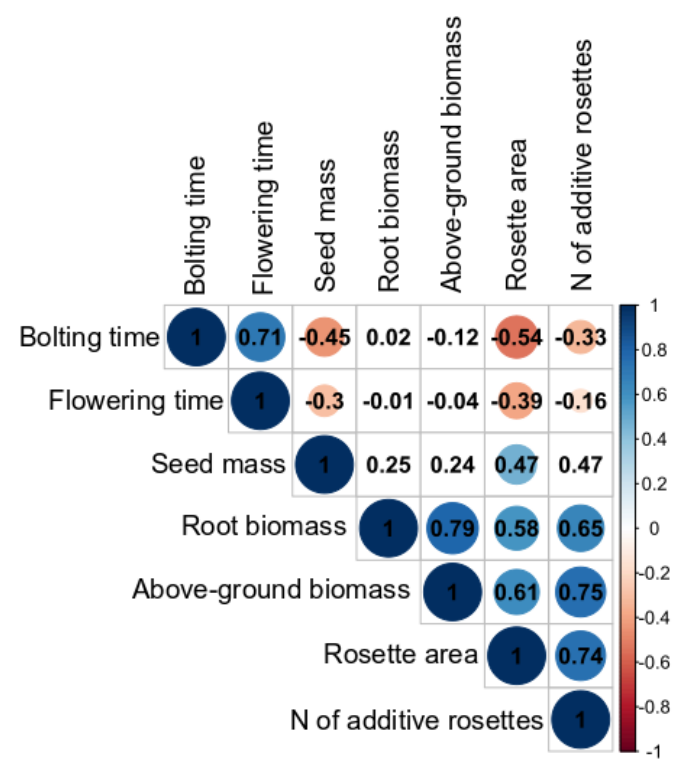

SFig. 2. Pairwise Spearman's correlations among fitness traits. Note: circle size denotes significance (larger circle=lower $p$ value), displayed are only circle sizes with $p<0.05$ ). 

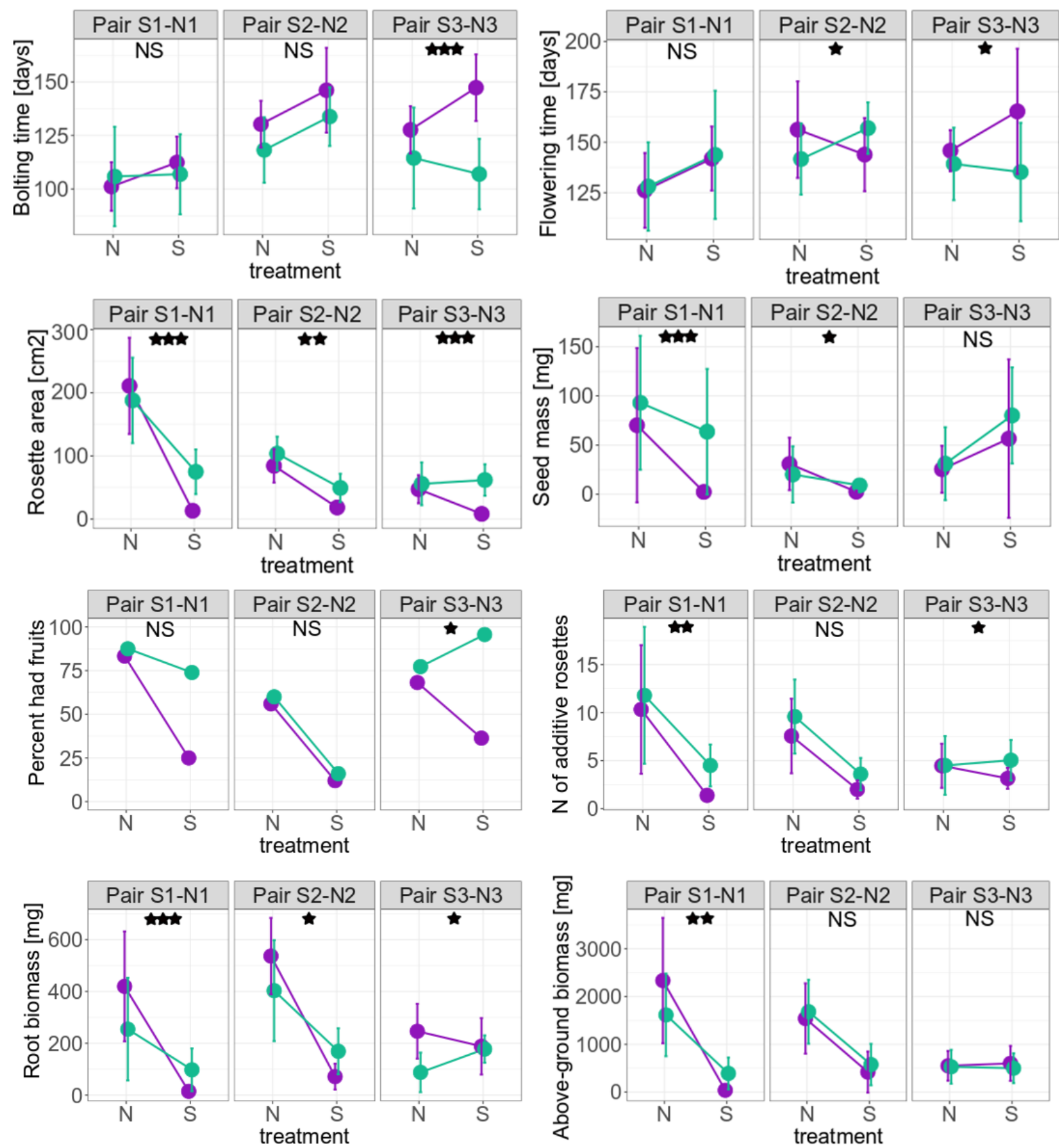

SFig. 3. Differences in vegetative and reproductive fitness traits of three population pairs cultivated in local serpentine $(\mathrm{S})$ and non-serpentine $(\mathrm{N})$ soils. Note: asterisks denote the significance of substrate of origin*treatment interaction within each population pair $(* * * p<$ 0.001 ; ** $p<0.01$; $p<0.05$; see Table S7); the percentage of plants that had fruits was counted from the total number of cultivated plants. 

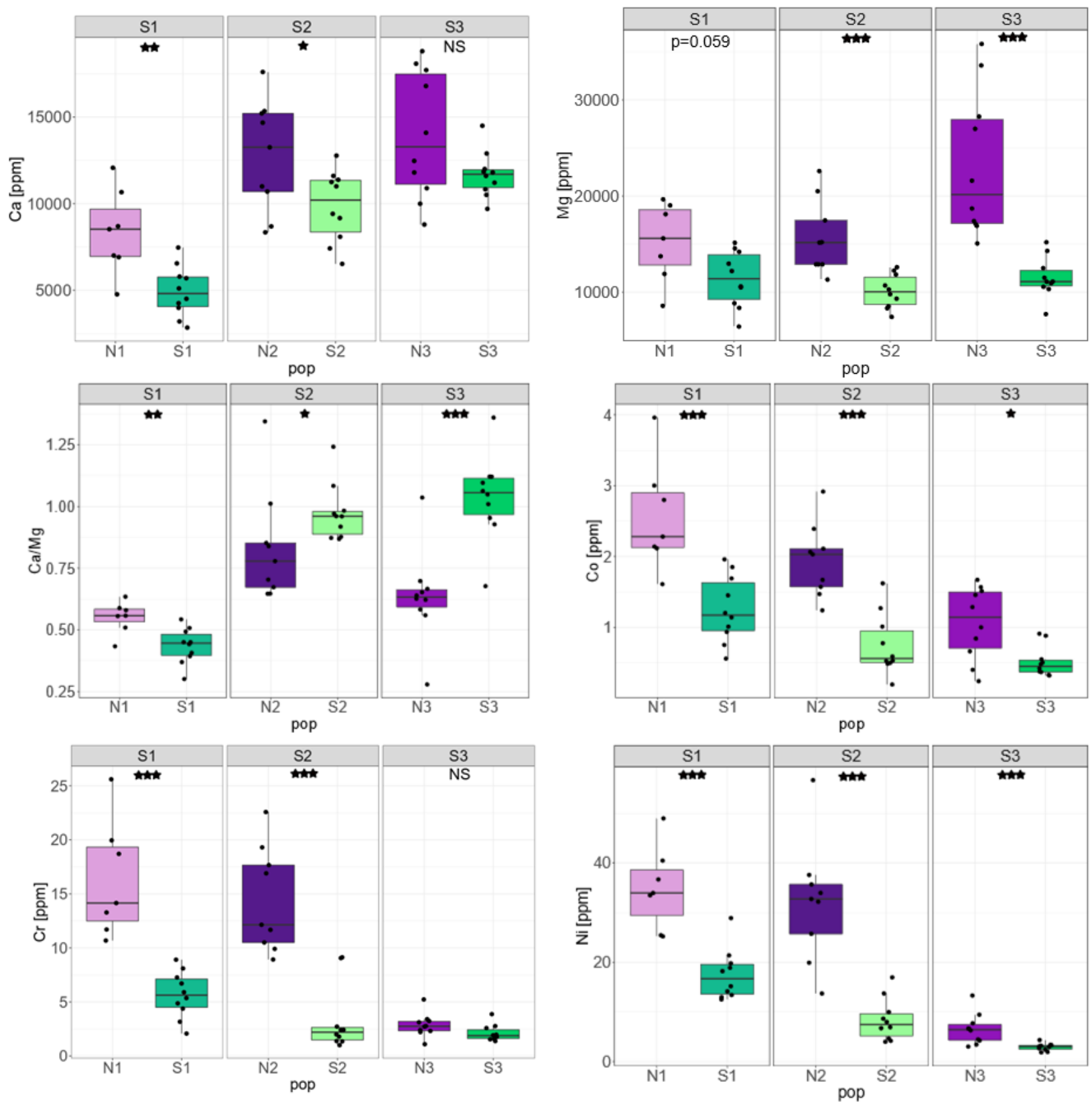

SFig. 4. Variation in the uptake of $\mathrm{Ca}, \mathrm{Mg}$, and exclusion of $\mathrm{Ni}, \mathrm{Co}$, and $\mathrm{Cr}$ in serpentine (S) and non-serpentine $(\mathrm{N})$ plants cultivated in serpentine soils (S1, S2, and S3). Note: asterisks denote the significance of the effect of substrate of origin $(* * * p<0.001 ; * * p<0.01 ; * p<=$ 0.05); elemental concentrations were assessed from plants after 6 months of cultivation; dots denote individuals. 